\title{
From Leonardo to the Next Rembrandt - The Need for AI-Pessimism in the Age of
} Algorithms ${ }^{1}$

\author{
Dr. habil. Péter Mezei
}

Associate Professor, University of Szeged, Faculty of Law and Political Sciences, Institute of

Comparative Law and Legal Theory. Adjunct Professor (dosentti) of the University of Turku

(Finland). Email: mezei@ juris.u-szeged.hu.

\section{Introduction}

Law is a fiction, ${ }^{2}$ and copyright law is an excellent example for legal fictions. All its norms, definitions, doctrines - e.g. creativity, originality, personality, economic and moral rights, limitations and exceptions, to name a few - are created and regularly re-created by human minds to serve metaphorical purposes. ${ }^{3}$ At the same time, copyright law is not a limitless fiction. It has its historical development, roots, subjects, objects, purposes and limits. The ultimate question of copyright law is nothing else than why and to whom do laws assign copyright protection? ${ }^{4}$ And the short answer to these questions is simple enough: expressions of the human mind shall be protected for the benefit of individual creators on the one hand and mankind in general on the other hand. This shall serve as a starting point and a guiding light when assessing the impacts and guessing the future of copyright protection of outputs/contents generated by Artificial Intelligence (AI).

The symbiosis of copyright protection and technological innovation dates back to centuries and has been closely connected ever since the modern movable type-based printing press was invented by Johannes Gutenberg. In most cases, both society and the rights holders have profited from this symbiotic interconnection, as the new technologies were created for the sake of humanity and rights holders became entitled for compensation. On the other hand, Jessica Litman pointed out that "[c]opyright laws become obsolete when technology renders the assumptions on which they were based outmoded". 5 New (disruptive) technologies have made copyright law fragile. This fragility was further exaggerated by the delayed (and occasionally ineffective) legislative reactions. Likewise, users have always been more willing to take advantage of innovations rather than strictly following the provisions of copyright law (and paying royalty to the authors). Unsurprisingly,

\footnotetext{
${ }^{1}$ The author of this paper would like to thank the organizers and participants of the meetings where parts of this paper were presented, including the $4^{\text {th }}$ Binational Seminar of the TU Dresden and the Charles University in Prague, June 27, 2019 [compare to Linke / Petrlík (2020) 39-45.]; the Rodin Museum's Moral Rights in the Serial Arts conference in Paris, October 18, 2019 (http://www.musee-rodin.fr/sites/musee/files/editeur/colloques/Droit Moral/Le droit moral dans les arts d'\%C3\%A9dition complet.pdf); the Centre for Intellectual Property Policy \& Management's Spring \begin{tabular}{llllll}
\hline Public Lecture & series & B & Birmingham,
\end{tabular} (https://microsites.bournemouth.ac.uk/cippm/2020/02/06/peter-mezei-from-leonardo-to-the-next-rembrandt-the-futur e-of-authorship-originality-and-moral-rights-in-the-age-of-algorithms/); and the LES Hungary's “Artificial Intelligence and IP" event, February 2020 (https://www.lesi.org/docs/default-source/meetings-committee/ip-it-les-hungary.pdf). The manuscript was closed on July 24, 2020.

${ }^{2}$ On legal fictions see Fuller (1967); Del Mar / Twining (2015). On legal fictions and copyright law see especially Ng Boyte (2014) 707-762.

${ }^{3}$ On metaphors and law see especially Larsson (2017).

${ }^{4}$ This paper aims to use copyright law as a term to describe authors' rights, related rights and sui generis protection. Wherever necessary, these terms/categories will be clearly separated.

${ }^{5}$ Litman (2006) 22.
} 
copyright laws and rights holders usually tried to eliminate or, alternatively, to control new technologies. The clash between the rights holders' and the society's interests speeded up by the emergence of digital technologies, and most importantly by the internet. ${ }^{6}$

Policy reports and scholarly papers on the protectability of computer generated contents were published as early as $1965 .^{7}$ While the intersection between AI and copyright law has been continuously discussed since then, it has become an extremely hot topic recently. ${ }^{8}$ Both the number and the depth of research on legal aspects of AI show an extreme growth. Many of these findings - e.g. related to the ethics, ${ }^{9}$ legal status, ${ }^{10}$ liability, ${ }^{11}$ competition law aspects, ${ }^{12}$ general regulation ${ }^{13}$ or the role of $\mathrm{AI}$ in comparative research ${ }^{14}$ - can have direct relevance for copyright law. The legal discussion of AI dominates a significant part of the copyright discourse and academic events these years.

While a significant amount of (let's call them AI-positivist) papers accept the idea of the protectability of AI-generated outputs, ${ }^{15}$ this paper follows a rather AI-pessimistic approach. Daniel Gervais questioned whether IP law is ready for AI. ${ }^{16}$ I believe that copyright law is neither ready for a paradigm shift, nor is it appropriate to protect AI-generated outputs. Carys Craig and Ian Kerr noted that any conclusion that copyright law's existing fictions shall be stretched to cover AI is "nonsense upon stilts". ${ }^{17}$ This paper agrees with this opinion and argues that copyright's old author-centric paradigm shall be retained. ${ }^{18}$ The key arguments will be closely connected to one single notion of copyright law, namely the author itself. The paper takes the view that the most fundamental (or core) elements of copyright law are deeply connected to human authorship. Indeed, as long as there is no convincing policy argument or legal and economic evidence to the contrary, the status quo of copyright law shall not be stretched to cover algorithmic creativity as well.

The structures of this paper is as follows. Chapter II focuses on the most important features of AI from a copyright perspective. This part is strictly target-oriented. Instead of conclusively defining AI from a scientific perspective (that this author is unable to do) I'll only filter out the key elements of algorithmic creativity, and discuss why is it imaginable at all that AI-generated outputs might be

\footnotetext{
${ }^{6}$ Tamura (2009) 63-74.; Mezei (2014) 75-79.

${ }^{7}$ See e.g. Samuelson (1986) 1192-1196.; Bridy (2012) 22-24.; Denicola (2016) 264-266 and 268-269.; Boyden (2016) 377-378.; Ihalainen (2018) 726.; Bonadio / McDonagh (2020) 115.

${ }^{8}$ The importance of the intersections between AI and IP might be mirrored by the number of recent editorials in the leading IP journals. See e.g.: Walz (2017) 757-759.; Ginsburg (2018) 131-135.; Bond / Blair (2019) 423.; Spindler (2019) 1049-1051.; Gervais (2020a) 117-118.; Castets-Renard (2020) 141-143.

${ }^{9}$ See e.g. Dettling / Krüger (2019) 211-217.; Magrani (2019) 1-19.; Larsson (2020) 1-23.

${ }^{10}$ See e.g. Atabekov / Yastrebov (2018) 774-782.; van den Hoven van Genderen (2018) 15-56.; Bennett / Daly (2020) 60-80.

${ }^{11}$ See e.g. Keßler (2017) 593-594.; Oster (2018) 14-52.; Revolidis / Dahi (2018) 57-79.; Garde (2018) 1132-1138.; Zech (2019) 198-219.; Lohsse / Schulze / Staudenmayer (2019).

${ }^{12}$ See e.g. Walz (2017) 757-759.; Beneke / Mackenrodt (2019) 109-134.

${ }^{13}$ See e.g. Pagallo / Corrales / Fenwick / Forgó (2018) 1-13.; Fenwick / Vermeulen / Corrales (2018) 81-103.; Turner (2018).

${ }^{14}$ Wolff (2019) 484-504.

${ }^{15}$ Compare to Chapter V below.

${ }^{16}$ Gervais (2020a) 117.

${ }^{17}$ Craig / Kerr (2019) 6.

${ }^{18}$ Ricketson (1991) 3.
} 
protected by copyright law. Chapter III provides a collection of notable examples for algorithmic creativity - ranging from music to movies, software, literature and fine art. This part is neither in favour nor against the protectability of AI-outputs. It only highlights that the "AI creative industry" certainly exists. Chapter IV raises four further (open) questions, and ultimately guesses whether copyright law is the right tool to protect AI-outputs. Chapter V answers the most important question of Chapter IV, and includes the AI-pessimistic approach of this author. It discusses five distinct, still closely interconnected issues/concepts of copyright law; namely, its history, its justifications, the concept of author, originality and moral rights. I believe that these fundamental pillars or core elements of copyright law speak against any protection of AI-outputs, and there is no conclusive evidence that would necessitate the overruling of the status quo. Chapter VI lists multiple ideas that other (both AI-optimistic and AI-pessimistic) authors raised as possible options to protect AI-generated outputs by (some form of) copyright law. This paper takes the view that the majority of these solutions are either unconvincing or ineffective. A very limited number of options might be acceptable theoretically, but testing them in reality (that is, providing some form of IP protection to AI-outputs) deserves careful ex ante analysis. Such analysis, especially economic modelling of the effects of AI-copyright on the original copyright industry and the "newcomers", is practically missing yet. In the final chapter, the paper concludes that the time has not come (yet) to fit emergent works into copyright law.

\section{What is Artificial Intelligence?}

Dreams of thinking machines, algorithms, artificial intelligence - tools that are first imagined by Ada Lovelace and Charles Babbage, ${ }^{19}$ and then put into reality by computer scientists like Claude Shannon and Alan Turing - came true. ${ }^{20}$ What AI really means (or should mean) is, however, a mystery - obscured by thick clouds. As Shlomit Yanisky-Ravid noted, "defining AI is not an easy task". ${ }^{21}$ This can easily be noticed in light of the recurring attempts to define AI that share common doctrinal elements (similarities) and show significant differences as well.

Pamela Samuelson called AI "a specialty field within computer science that is aimed at producing computers that exhibit intelligent conduct". 22 Amit Konar viewed AI as the "simulation of human intelligence on a machine, so as to make the machine efficient to identify and use the right piece of 'Knowledge' at a given step of solving a problem". ${ }^{23}$ Nils J. Nilsson opined that "AI is that activity devoted to making machines intelligent, and intelligence is that quality that enables an entity to function appropriately and with foresight in its environment". ${ }^{24}$ The European Commission defined AI as "systems that display intelligent behaviour by analysing their environment and taking actions - with some degree of autonomy - to achieve specific goals". ${ }^{25}$ According to Florian De Rouck "AI systems will be designed to perform human-like cognitive tasks, steadily

\footnotetext{
${ }^{19}$ On the calculating machine and the analytical engine, as well as Lovelace's and Babbage's collaboration see Gleick (2011) 115-120.

${ }^{20}$ On Turing's universal machine and Shannon's rat see ibid. at 204-268.

21 Yanisky-Ravid (2017) 673.

22 Samuelson (1986) 1186., note 1.

${ }^{23}$ Konar (1999) 1.2.

24 Nilsson (2010) 13.

25 Artificial Intelligence for Europe, $\operatorname{COM(2018)} 237$ final, 1. See in greater details: High-Level Expert Group on Artificial Intelligence (2019) 8.
} 
improving their performance by learning from experience or external data" ${ }^{26}$ Finally, Mauritz Kop, citing Stephen Hawking, argued that AI is "a non-human system that possesses cognitive functions and skills such as learning and reasoning. A smart computer that can think and plan strategically. A science that can assist humanity to find answers to the big questions/themes we face". ${ }^{27}$

AI can be either a software or a hardware ${ }^{28}$ and it can be a system, an entity and a science as well. ${ }^{29}$ More importantly, depending upon the independence and the "creativity" of the given software or hardware, we can differentiate between strong (full), general or weak (narrow) AI. ${ }^{30}$ This latter category is what matters the most from the perspective of copyright law. From mere tools or assistants to human activities, algorithms, robots or machines have become "creators" (or generators in my understanding) of information. ${ }^{31}$

The creation of/with AI has three main stages: (1) coding; (2) input, training or machine learning; and (3) output. ${ }^{32}$ Coding is mainly a human privilege (yet), and input/training is also heavily overseen by humans in the majority of cases. Various algorithms (most importantly Artificial Neural Networks or strong AI) are coded in a way that they are capable of learning autonomously, that is, to select the input they are willing to analyse. Indeed, "machine learning algorithms can rewrite themselves". 33 In sum, a significant amount of output might be generated by the machine with no causal connection between the original human programmer and the final output - usually coined as computer-generated (or emergent, generative or procedurally generated) "works". 34

The real challenges to copyright protectability might come from this part of AI. As long as a machine or algorithm is only a mere tool or assistant to a human creator, copyright law is more or less ready to classify the final output as a protectable subject matter. Challenges arise as soon as the causal link between the human coder or end-user and the output fades. We will continue to focus on this latter situation. ${ }^{35}$

\section{AI in the creative industries}

AI is a part of our daily life. ${ }^{36}$ Many of us use automatic word processing and translation services, commute with GPS-navigation offering real-time traffic data (based on the geolocation function of our cell phones), use chatbots to file our complaints or request information from various corporation, or discuss any questions with virtual assistants like Siri. AI is used in sports, health

\footnotetext{
${ }^{26}$ De Rouck (2019) 432.

27 Kop (2020a) 4.

28 Artificial Intelligence for Europe, COM(2018) 237 final, 1.; Yanisky-Ravid (2017) 673-674.

${ }^{29}$ Kop (2020a) 4.

${ }^{30}$ On the technological aspects of the various forms of AI and machine learning see Noto La Diega (2018) 98-101.; Rohner (2019) 46-51.; Ballardini / He / Roos (2019) 119-121.; Wolff (2019) 487-489.

${ }^{31}$ Compare to Gervais (1991) 628-654.

${ }^{32}$ Gervais (2020b) p. 5-7.

33 Zech (2019) 1145. As Zech also noted: “[n]owadays, artificial neural networks may reach a complexity of up to $10^{8}$ 'simulated neurons' with up to $10^{11}$ 'simulated synapses"'. Ibid. at 1146.

${ }^{34}$ De Rouck (2019) 434.

35 Compare to Dornis (2019) 1253-1254.

36 See e.g. Denicola (2016) 253-254.; Keßler (2017) 589-590.; Yanisky-Ravid (2017) 664-666.; Yanisky-Ravid / Velez-Hernandez (2018) 4-6.; Ginsburg / Budiardjo (2019) 396-398.
} 
care, weapon industry, robotics, virtual reality, fintech, retail stores, digital marketing, fashion industry, and it is the holy grail of self-driving cars. ${ }^{37}$ Museums and other members of the "art industry" also use AI as a part of their services; e.g. humanoid/anthropomorphic robots to learn the reactions of visitors, ${ }^{38}$ provide help to the visitors, ${ }^{39}$ apps based on image recognition technology to support museumgoers to identify artworks, ${ }^{40}$ or to measure the value/price of an artwork. ${ }^{41}$ Robot AI might be able to foresee global epidemic, ${ }^{42}$ and hence support the fight against humanitarian catastrophes. ${ }^{43}$ Big data would also remain an uncontrollable ocean of information without algorithms.

AI has an exponentially growing relevance in the copyright industry as well. AI is both a topic of creative contents (object) and the generator of such contents (subject). A vast amount of motion pictures focus on the life, feelings, love and fate of AI in an anthropocentric world; ${ }^{44}$ the way how artificial creations (machines, algorithms or even Replicants) confront with humans; ${ }^{45}$ and how machines might create art. ${ }^{46}$ In the movie industry, AI might be effectively used for marketing purposes, e.g. for selecting the best possible date of cinema releases. ${ }^{47}$ It won't take too much time to see the first ever movie with an A.I. robot in the "female lead role". 48

The list of algorithmic compositions grew long as well. Iamus, ${ }^{49} \mathrm{EMI}^{50} \mathrm{AIVA}^{51}$ or Jukedeck ${ }^{52}$ evidence machines' ability to generate new musical contents. ${ }^{53}$ Algorithms are ready to finish symphonies, ${ }^{54}$ to compete on a "Eurovision" contest dedicated to algorithms, ${ }^{55}$ or to generate parodies of existing works. ${ }^{56}$ Indeed, they are capable to translate the spike protein (the structure)

${ }^{37}$ Hao (2019); Keh (2019); Metz (2019); Kessel (2019); Grady (2019); Alba (2019); Wakefield (2020); The Economist (2020); Palazzetti (2020).

${ }^{38}$ On Musee du quai Branly's "Berenson", the robotic art critic see Munro (2016).

${ }^{39}$ On "Pepper", the humanoid robot of Smithsonian see Alpeyev (2018).

${ }^{40}$ On "Magnus" see Haigney (2019).

${ }^{41}$ Bailey(2020).

${ }^{42}$ Prosser (2020).

${ }^{43}$ Broad (2020); Carey (2020).

${ }^{44}$ Compare to movies like "Ex Machina" or the South-Korean popular TV-show "I am not a robot".

${ }^{45}$ Compare to movies that tell us modern Frankenstein stories, e.g. "The Terminator" or the "Matrix" saga, the clash of HAL and the astronauts in "Space Odyssey 2001", the hunt for Replicants in "Blade Runner" (even though Replicants were not "machines", but bioengineered beings).

${ }^{46}$ Compare to the fight robot Chappie in "CHAPPiE", Ava in "Ex Machina", or my personal favourite, Andrew Martin (NDR-113) in "Bicentennial Man". On Ava in "Ex Machina" see Yanisky-Ravid (2017) 667.; Yanisky-Ravid / Velez-Hernandez (2018) 7. For further examples from various movies see Craig / Kerr (2019) 1-2.

${ }^{47}$ Siegel (2020).

${ }^{48}$ Keegan (2020); Bahr (2020).

${ }^{49}$ Ball (2012). See further Denicola (2016) 264.

50 Johnson (1997). See further Deltorn / Macrez (2018) 17-18.

51 “AIVA: The Artificial Intelligence composing emotional soundtrack music". See https://www.aiva.ai/.

${ }^{52}$ Featherstone (2017). See further Bonadio / McDonagh (2020) 112.

${ }^{53}$ For further examples see e.g. Deltorn / Macrez (2018) 3. and 5-6.; Ralston (2005) 283 and 287-288.

${ }^{54}$ See e.g. Boxall (2019); Huggler (2019). The premiere of Beethoven's AI-finished symphony was scheduled for the end of April 2020, but it was postponed to November 2020 due to the COVID-19 epidemic. See Horseman (2020).

${ }^{55}$ Nic Fildes: When AI Takes on Eurovision: Can a Computer Write a Hit Song?, ArsTechnica, May 11, 2020 (https://arstechnica.com/gaming/2020/05/when-ai-takes-on-eurovision-can-a-computer-write-a-hit-song/).

${ }^{56}$ The contents of "Weird A.I. Yancovic" (mimicking the name of the famous music parodist, Weird "Al" Yancovic) are generated by two neural networks, GPT-2 and XLNET. Mark Riedl, the founder of the project has to face, however, legal challenges of its model. Two months after the posting of the "artificial parody version" of Michael Jackson's "Beat it" on Twitter, IFPI requested the take-down of the content. See Truong (2020). 
of SARS-CoV-2 into classic music (that researchers believe to help understanding the functioning of COVID-19 and to fight the global epidemic it caused). ${ }^{57}$

AI scored significant victories in the domain of art. The Next Rembrandt project gained a lot of publicity, ${ }^{58}$ as well as the sale of the AI-generated Portrait of Edmond Bellamy by the auction house Christie's for 432,500 USD. ${ }^{59}$ Although it is not "classic art", but e-David generates portraits with its "artificial brushes", ${ }^{60}$ and the futuristic dream images of DeepDream ${ }^{61}$ look significantly creative in a traditional copyright sense. ${ }^{62}$

AI - or simply robots - has long been the object of classic science-fiction literature, ${ }^{63}$ but it has already become a subject/source of such "creativity" as well. Projects like Ray Kurzweil's Cybernetic Poet ${ }^{64}$ AARON ${ }^{65}$ BRUTUS, ${ }^{66}$ or Racter $^{67}$ show the capacity of AI to generate literary works, from haikus to novels. ${ }^{68}$ Some outputs are as entertaining (and some are as boring) as human works. Artificial poets and novelists might need to be ready to e-dedicate their works for their human readers, if this trend continues.

AI also became more than a tool in the news industry. RADAR, with significant human intervention, creates automated news reports; ${ }^{69}$ Automated Insights' and Narrative Science's algorithm reports about sports events; ${ }^{70}$ Quakebot, developed by the Los Angeles Times, reports on earthquakes in California. ${ }^{71}$ The protection of such AI might become a reality soon. In China, for example, a court ruled in early 2020 that Tencent has valid copyright claim over the articles produced by the corporation's Dreamwriter algorithm. ${ }^{72}$ As the Court argued, direct connection (or causal link, as I argued above) existed between the editorial team's creative choices and the final output of the algorithm. The selection, judgment and skills of the editorial team's members and the above-the-minimum level of creativity of the outputs ultimately allow for the protection of the news reports by copyright for the benefit of the publisher (the employer of the editors). ${ }^{73}$

\section{Open Questions of the Future of AI and Copyright}

\footnotetext{
${ }^{57}$ Lang (2020).

58 See https://www.nextrembrandt.com/. See further Yanisky-Ravid (2017) 663., note 5.; Yanisky-Ravid / Velez-Hernandez (2018) 3-4.; Maggiore (2018) 383-384.; Zibner (2019) 3.

${ }^{59}$ Cohn (2018). See further Lauber-Rönsberg / Hetmank (2019) 570.; Dornis (2019) 1253.; Craig / Kerr (2019) 3-4.

${ }^{60}$ Starr (2013). See further Yanisky-Ravid (2017) 662-663.

61 See https://deepdreamgenerator.com/. See further Guadamuz (2017) 171-172.; Palace (2019) 223-224.

${ }^{62}$ For further examples see e.g. Craig / Kerr (2019) 2-3.

${ }^{63}$ Compare to Isaac Asimov's Robot Universe, which is the richest literary source on the future of robotics.

64 Poetry by the Cybernetic Poet, Kurzweil Cyberart Technologies (http://www.kurzweilcyberart.com/poetry/rkcp_how_it_works.php). See further Bridy (2012) 15.

65 Anderson (2001). See further Denicola (2016) 263-264.; Ginsburg / Budiardjo (2019) 411-418.

${ }^{66}$ Rensselaer Polytechnic Institute (1998). See further Bringsjord / Ferrucci (2000).

${ }^{67}$ See https://archive.org/stream/pdfy-T3abGAQ80ecd63PL/racter_policemansbeard_djvu.txt. See further Ramalho (2017) 12.; Palace (2019) 220-221.

68 Such a notable example is "The Day a Computer Writes a Novel", which was - less surprisingly - a novel written by an algorithm. See Schiller (2016). See further Yanisky-Ravid (2017) 668.; Ihalainen (2018) 725.

69 See https://pa.media/radar/. See further De Rouck (2019) 433-434.

70 Beckett (2015). See further Denicola (2016) 257-259.; Palace (2019) 224-225.

${ }^{71}$ Oremus (2014). See further Boyden (2016) 380-381.; Denicola (2016) 257.

${ }^{72}$ Yan (2020); O’Neill (2020). On a detailed analysis of AI under Chinese copyright law see He (2019) 218-238.

73 Tencent Dreamwriter (2020) 652-659.
} 
Before turning to my arguments against the introduction of any norms on AI-copyright, we shall address a few open questions of this field.

First, do we face any "AI winter" yet? AI-science has chilled at least twice since research on this field started many decades ago. ${ }^{74}$ In light of the continuous development of Artificial Neural Networks, the enormous amounts of funding involved, ${ }^{75}$ as well as the fact that AI has become a part of our daily routine, ${ }^{76}$ we might tend to believe that no significant AI winter is ahead of us anymore. Critical voices exist, though. Some have noted that the hysteria around AI "could actually end up turning people against AI research, bringing significant progress in the technology to a halt". ${ }^{77}$ Or as a columnist wrote: “[t]oday's 'AI summer' is different from previous ones. It is brighter and warmer, because the technology has been so widely deployed. Another full-blown winter is unlikely. But an autumnal breeze is picking up". ${ }^{78}$

Second, will future AI algorithms need any human intervention at all? This question might look naïve as we already have strong AI that generates outputs without human contribution. We need to stress, however, that coding of AI (the first step of the AI-process) is still dominantly a human domain. Furthermore, not all AI can generate outputs autonomously. The success of algorithms depends heavily on human participation in the creation process yet. The best example here might be The Next Rembrandt project. There, programmers taught the algorithm and selected the features of the new "painting" as well. The ultimate creation of the output was done by the AI itself, but strictly bound to programmers' decisions. The same is true for RADAR, as introduced above. In short, human participation in the "AI industry" remains necessary for a period of time. This also means that challenging copyright's status quo is not an urgent task yet.

Third, will there be any market/need for AI-generated contents? At first sight, this question might be outdated, since the sale of the Portrait of Edmond Bellamy evidences that there is at least some market for some emergent works. Still, we shall remain cautious with generalizing the relevance of the Christie's auction. On the one hand, the sale of AI artworks by auction houses is still the exception rather than the rule. On the other hand, the mere sale of any output does not necessitate any legislation on this field. In the lack of empirical evidence, we are unable to measure whether AI-generated outputs could replace human creations on the market or not. ${ }^{79}$ It is similarly far from certain that the successful sale of the Portrait of Edmond Bellamy could be repeated in other fields of the creative industry. While art is quite subjective, the biological differences of the inception of various artworks are significant. Harmony and logic has for example more relevance in the field of music or literature. Random words bear no meaning, but random brush strokes might be visual art. Finally, "market" is neither only about the quality of the given content, it is also about branding. While AI-generated music is a reality, there is no guarantee that humans would find AI-music more

\footnotetext{
${ }^{74} \operatorname{Lim}(2018)$.

75 Deltorn / Macrez (2018) 4.

76 "If, for several decades, AI experienced waves of enthusiasm and setbacks ("winters" of AI), it is now part of everyday life, whether it is using a personal virtual or virtual assistant, or travelling in a semi-autonomous vehicle." See Castets-Renard (2020) 141.

77 Naudé (2019).

${ }^{78}$ Cross (2020).

${ }^{79}$ Lauber-Rönsberg / Hetmank (2019) 578.
} 
appealing and would purchase more tickets to a Compressorhead ${ }^{80}$ concert than to a Motörhead event. (We have no evidence to the contrary either.) We lack empirical and economic evidence regarding the marketability of AI-outputs, which is a great concern from a policy perspective.

Fourth, is there any real need to protect AI-generated outputs by copyright law? In her study on the "European Civil Law Rules in Robotics", Nathalie Nevejans took the view that "[t]here is no need to overhaul the whole body of literary and artistic property law, but merely to adjust it in the light of the autonomous robots' new/future abilities". ${ }^{81}$ I am not confident that this is a correct opinion. Copyright law is a complex net of various concepts, doctrines, theories and rules. Stretching this net to fit AI into copyright law does neither look an easy task nor a wise decision. Some elements of copyright law can easily be applied in an AI environment, even in the lack of any paradigm shift. For example, software programmers, who develop an algorithm and contribute to the causal link between the input and the output, might fit into the concept of author. ${ }^{82}$ Similarly, the existing rules on the copyright and sui generis protection of database authors and database makers/producers, respectively, might be applied to a certain level. ${ }^{83}$

Emergent works trigger more uncertainties. What legislative justifications can serve as a basis for the protection of emergent works? What about exclusivity of rights or monopolies? Shall we grant exclusive rights to those algorithms that might flood the market with an unlimited amount of outputs? Shall we grant personality and moral rights to AI? Who shall have the ownership interests over the AI-generated outputs? Shall we find a human behind the machine? Shall we analogically apply the work-made-for-hire doctrine in the AI environment? What about originality? Can AI be intellectual, creative and expressive? How to count the term of protection, if algorithms do not age? Shall autonomous machine learning comply with the existing limitations and exceptions of economic rights? Shall we use the rules on technological protection measures and rights management information to AI outputs as well? Without the lack of any personality on AI's side, who shall bear the liability or accountability for any possible infringement of others' copyrights (during the coding, learning and output phases)? Who and how can enforce any possible rights in favour of AI? Who shall enjoy the benefits (harvest the fruits) and receive any rewards for the misuse of any AI-generated output? Will AI have any standing to defend itself or sue others? And this list might easily include further dozens of similar questions.

In short, copyright law is far more complex than allowing a mere "adjustment" to fit AI into its domain. Indeed, relying on the sports language of American football: the ruling on the field might only be reversed if there is any indisputable (conclusive) evidence for the reversal. More clearly: the status quo of copyright law might only be overruled or stretched if there is significant and balanced evidence that AI deserves an equivalent level of protection with humans. Otherwise we might run into a serious trap. As Jan Zibner noted, "[ $\mathrm{t}]$ o regulate an uncertain phenomenon with no strict terminology and understanding (...) is challenging". 84

\section{The ruling on the field...}

${ }^{80}$ Compressorhead is a "robot band". Its robot musicians present (let's skip calling it perform) human made compositions. See e.g. Leonard (2013).

${ }^{81}$ Nevejans (2016) 6.

${ }^{82}$ Hristov (2017) 435.; Lauber-Rönsberg / Hetmank (2019) 572-573.; Nägele / Apel (2020) 297-299.

${ }^{83}$ Noto la Diega (2018) 113-149; Nägele / Apel (2020) 299-301.

${ }^{84}$ Zibner (2019) 8. See further Nägele / Apel (2020) 289. 
I often use the metaphor of an ancient Greek temple to describe copyright law in general. An ancient Greek temple has three main parts: the foundations and crepidoma; the columns; and the entablature (including the most decorated, top triangle-shaped tympanon). ${ }^{85}$ In a pure metaphoric sense, the foundations and crepidoma of the temple of copyright is its history and the incentives that the system is based on. The columns of the temple are the doctrinal elements of the existence of copyright law, e.g. the author and related rights holders; originality (threshold of protection); subject matter; economic and moral rights; limitations and exceptions; term of protection. The entablature of the temple of copyright are the tools, methods and practices how copyrights are exercised and enforced. Five elements of this metaphoric temple require careful analysis in order to decide, whether AI-generated outputs can fit into the concept of copyright law. These are the history of copyright, copyright incentives, the concept of authorship, originality, and moral rights. I believe that these core elements of the regime run against the inclusion of emergent works in copyright law. As long as AI-outputs do not fit into or fulfil the requirements of these "core elements", we cannot talk about AI-copyright at all.

\section{Copyright's short history}

The emergence of copyright protection is due to the appearance and conjunction of four different factors. First, the (European) invention of the printing press replaced manual multiplication with massive reproduction of written works (mainly books), and made the copies marketable. We might call this factor the "material side" of copyright's history. Second, individualism and the Renaissance increased the interest of self-expression as well as the protection of the personal/intellectual interests of authors. We might call this factor the "personal side" of copyright's history. Third, with the advent of public education as well as the Renaissance's artistic explosion, citizens' demand to become owners of physical copies of intellectual creations culminated in a new copyright ecosystem. We might call this factor the "market/consumption side" of copyright's history. Fourth, for various centuries (from the $15^{\text {th }}$ to the $18^{\text {th }}$ century), kings or other leaders of European countries/cities granted "patents" to specific printers to exclusively print specific or all books at a designated geographical territory. ${ }^{86}$ It took centuries to learn that these monopolies do not serve the society in general. It was only in 1709 that the English political environment became ready to settle and regulate the copyright ecosystem. ${ }^{87} \mathrm{We}$ might call this factor the "legislative side" of copyright's history. ${ }^{88}$

A look at the first ever copyright acts of the world might evidence the basic rationale of copyright law. In England, before the Statute of Anne came into force on April 10 ${ }^{\text {th }}, 1710$, the Stationers Company controlled book publishing. ${ }^{89}$ The Company's monopoly was based on its role as a censor on behalf of the Crown. ${ }^{90}$ The interests of the authors were rarely articulated. The authors could sell their "copy rights" to the printers for a one-time fee, but they did not receive a share from

\footnotetext{
${ }^{85}$ Cautious readers might notice that the structure of an Ancient Greek temple is much more sophisticated, partially depending upon the relevant order (Ionic, Doric or Corinthian), than the short generalization I used above. On Ancient Greek architecture see in details: Barletta (2001).

${ }^{86}$ See e.g. Matthews (1890) 587-589.; Ginsburg (2016) 237-267.

${ }^{87}$ Compare to Rose (2010) 67-88.

${ }^{88}$ Mezei (2014) 73-75.

${ }^{89}$ Compare to e.g. Gadd (2016) 81-95.

${ }^{90}$ Matthews (1890) 589-590.
} 
the income that the Company generated from the publications. The Company and its censorship turned to be a limitation to a prospering publishing market and national literature in the $17^{\text {th }}$ century. John Milton (in his Areopagitica) and later Daniel Defoe argued in favor of the elimination of censorship and the introduction of freedom of press, as well as the legislative protection of authors. The Statute of Anne finally eliminated the Company's monopolies, declared that the rights of reproduction and distribution should be vested in the authors for a limited (but renewable) period of time, and introduced the doctrine of public domain. ${ }^{91}$ Based on the IP Clause of the Constitution, ${ }^{92}$ the first Copyright Statute of the United States, introduced in 1793, intended to "promote the progress of science and useful arts". The law thus aimed to reach a balance between the interests of the creators and the society as a whole. The basic objective of the first French Copyright Statute (the so called "Chénier Act"), similarly created in 1793, during the bloody years of the French Revolution, was to introduce liability for the content of the citizens' speech. ${ }^{93}$ Irrespective of the different economical, technological, intellectual, social and political challenges that these countries faced in the $18^{\text {th }}-19^{\text {th }}$ century, these first copyright acts were common in the protection of individual human authors on the one hand, and in serving the interests of the general public on the other hand.

The history of copyright law undeniably proves that the development of technology has instigated the most legal changes. At the same time, as Rochelle C. Dreyfuss correctly noted, IP law has also enabled the various industrial revolutions: "[ $\mathrm{t}]$ raditional forms of intellectual property rights (patents, copyrights, and trademarks) created strong incentives to expend time, effort, and money on producing the advances that gave rise to the Information Age". 94

Yoshiyuki Tamura depicts the joint evolution of technology and copyright law with three "waves". The first wave was the European invention of the printing press. In Tamura's opinion the second wave came in the second half of the $20^{\text {th }}$ century with the appearance of analogue reproduction technologies, when a larger portion of the society became able to copy protected materials at home. Digital technologies and the internet brought the third wave, as they allow for easy, fast and cheap access to and use of protected subject matter in the digital domain. ${ }^{95}$ Irrespective of Tamura's selective conception (it merely disregarded technologies that were related to the appearance of audio and audiovisual contents, e.g. photographs, camera, motion pictures, radio, sound recordings etc.), his theory correctly points out that most of the challenges and changes to the copyright system were induced by the newly invented technologies in the last three centuries. At the same time, the technological development has always correlated with the consumers' needs, as well as their service to the society and to the rights holders as well. ${ }^{96}$

In sum, irrespective of the effects of various technological achievements on law and society as well as the emergence of corporate interests, and ultimately the dominance of trade related aspects of intellectual property over the romantic concept of authorship, copyright's history evidences that

\footnotetext{
91 Patterson / Birch / Joyce (2009) 244-256.

92 See US Constitution Article 1., Section 8., Paragraph 8. On the relevance and meaning of the IP Clause see further Bracha (2016) 342-346.

93 Latournerie (2001) 43-46. On the historic development of French copyright law see in great details: Rideau (2016) 391-422.

${ }^{94}$ Dreyfuss (2020) 2. See further Grosse Ruse-Khan (2020) 3.

95 Tamura (2009) 66-68.

96 Regarding the development of protection of musical works see e.g. Mezei (2014) 77-78.
} 
the ultimate goal of copyright law has always been to serve individual authors' human-centric and the human society's general commercial and cultural purposes - in short: the cultural and economic development of humankind. As we have seen above, AI is such a broad concept (hardware, software and science at the same time) that it can serve the human society's goals in a broad sense. Just recall the AI-led research in the fight - and hoped triumph over - global epidemics that seriously hamper economic, social and cultural development. Nevertheless, AI's general advantages do not mean that algorithms shall be treated on an equal level with humans' individual or collective interests. Copyright history is unquestionably a human history. Indeed, as subject matter has been historically connected to human authorship under the Berne Convention, emergent works would not enjoy the multinational protection of the Convention at all, even if their countries of origin would protect AI by copyright. ${ }^{97}$

\section{Copyright Incentives}

A myriad of researchers discusses the justifications of copyright protection. Only to name a few, William Fisher, in his widely cited paper spoke about welfare, fairness, culture and social planning theories. ${ }^{98}$ Shlomit Yanisky-Ravid mentioned law and economics, personality, labour theories. ${ }^{99}$ Takashi Yamamoto differentiated between labour, personality, incentive and vehicle theories. ${ }^{100}$ Carys Craig and Ian Kerr recognized deontological (personality and labour) and teleological (utilitarian) theories. ${ }^{101}$

This paper is unable and unwilling to judge which opinion is the most convincing. I therefore use the most well-known expressions, and I'll differentiate between three main forms of justifications of copyright law: the personality, the labour and the utilitarian theories. It is worth noting that no copyright regimes are based on any single justifications like these; indeed, all countries rely on a mixture of various theories. ${ }^{102}$ Even the most utilitarian copyright regimes respect the personality of authors, ${ }^{103}$ and, vice versa, "it's all about the money" in the most author-centric regimes as well.

What matters more, for the purposes of this paper, is that both the personality and the labour theory are strictly connected to an individual creator's personal achievements. While the labour theory focuses more on the invested energy and hard work of that person, and the personality theory focuses more on the intellectual/metaphysical bond between the author and "her child", both justifications admit that protection is granted to the human author for the creation of the intellectual output.

\footnotetext{
97 Ginsburg (2018) 134-135.

98 Fisher (2001) 168-199.

99 Yanisky-Ravid (2017) 699-707.

100 Yamamoto (2018) 4-8.

101 Craig / Kerr (2019) 32-33. For further discussions related to incentives and artificial intelligence see e.g. Bently / Sherman (2009) 34-39; ; Ramalho (2017) 18-20.; Rohner (2019) 70-74.; Dornis (2019) 1257-1258.

102 Ginsburg (1990) 991-1031.; Ricketson (1991) 4-8.

103 "Utilitarianism, in short, does not escape the ideological clutches of the romantic author-function. Moreover, the individualized, atomistic self of liberal theory that supports and overlays the romantic author figure is positively vibrant in utilitarian theory." See Craig / Kerr (2019) 35. Or as Monroe Price and Malla Pollack put it, "the intention central here is the intention to profit from the system - not the intention to create masterpieces". See Price / Pollack (1992) 713.
} 
The labour and the utilitarian concepts share another common point: copyright protection is granted to reward the intellectual (occasionally physical) investment in the creation and to incentivise any future creations. Under these concepts, the author (be it a human or a "deemed author", e.g. a corporation) shall enjoy the fruits of her work.

Irrespective of the justification(s) that a given country applies in its copyright regime, all theories are inherently bound to the concept of author. In an AI-environment, the personality right justification shall be declined per se, as long as algorithms do not have any e-personality (which is not the case yet). The labour and the utilitarian concepts might look applicable to a certain level to emergent works, as these theories focus on the reward and the incentives of creation rather than on the creator itself. Algorithms, however, rarely have any interests in rewards and incentives. Daniel Gervais noted perfectly that "if an AI machine is programmed to 'create', it requires no ex ante legal incentive or ex post reward for doing so". ${ }^{104}$ No doubt, several policy considerations might argue for the introduction of AI-copyright. Kalin Hristov noted that the copyright status quo might chill innovation in general or the developers to create, use and improve the AI machines' capabilities, as well as limit the number of available works for teaching, research or other purposes. ${ }^{105}$ Similarly, Robert $C$. Denicola was on the view that "a work's contribution to the public welfare does not seem dependent on the process that produced it", hence it seems to be socially desirable to extend copyright protection to emergent works. ${ }^{106}$

It seems so that the existing copyright status quo might only be amended or extended to emergent works, if there is any new, convincing justification to cover AI-generated outputs. At the moment, we are not aware of proper evidence on the detrimental effects of the lack of AI-protection. In sum, there are more convincing arguments against than in favour of the protection of emergent works under the leading copyright justifications. ${ }^{107}$

\section{The concept of authorship}

Copyright statutes, as well as international copyright treaties fail to define one of the most important elements of the regime, namely the concept of "author". Commentators of the Berne Convention confirm that the lack of the definition is generally due to the common understanding among the Member States that authors are those humans, who create the original works of expression. ${ }^{108}$ Even in the silence on authorship, the Berne Convention necessitates to the same conclusion by requiring that authors are nationals of the Member States of the Union, as nationality can only be granted to human individuals. ${ }^{109}$ The same result can be reached through a

\footnotetext{
104 Gervais (2020b) 48. See further Samuelson (1986) 1199.

105 Hristov (2017) 438-439.

106 Denicola (2016) 273.

107 Noto La Diega (2018) 107-108.; Rohner (2019) 79.

108 Ricketson / Ginsburg (2005) 358.
}

109 Berne Convention, Art. 3. Compare to Nordemann / Vinck / Hertin / Meyer (1990) 43.; Ricketson (1991) 8-10.; Gervais (1991) 643-644. Article 4(a) opens the door for a broader authorship concept with respect to cinematographic works, as it allows for the application of the Convention to makers of these works if they are headquartered - that is, they have legal personality - in any of the Member States. Compare to Article 15(1) as well, which says that "[i]n order that the author of a literary or artistic work protected by this Convention shall, in the absence of proof to the contrary, be regarded as such, and consequently be entitled to institute infringement proceedings in the countries of the Union, it shall be sufficient for his name to appear on the work in the usual manner. This paragraph shall be applicable even if this name is a pseudonym, where the pseudonym adopted by the author leaves no doubt as to his identity." 
fundamental/human rights approach. Both the Universal Declaration of Human Rights and the International Covenant on Economic, Social and Cultural Right ${ }^{110}$ grant human rights to "everyone" - where "everyone" practically means "humans". 11 This logic is further supported by case law. The CJEU concluded in various cases that originality (and therefore copyright protection) requires that authors shall put their personal touch on their intellectual creations. ${ }^{112}$ Since the seminal Trade-mark Cases, ${ }^{113}$ US courts often use the expression "creation of the mind" in this context - and there they refer to human minds. ${ }^{114}$ In sum, domestic copyright regimes are generally based on the "originalist premise" of authorship.

Copyright acts, however, protect others than humans as well. The European Union's Software Directive - through a legal fiction - expressly allowed for the Member States to grant authorship status to legal persons. "115 Another example for "deemed authorship" comes from the work-made-for-hire doctrine. According to it, an employer (or commissioner), including legal persons, might automatically be treated as the author of the work that originates from the employee (commissioned person), or it might contractually acquire the copyrights related to the given work. The classic European related rights break the anthropocentric system of copyright law by granting separate rights to producers of films, sound recordings and other corporations, e.g. broadcasting organizations; and by allowing for transfer of copyrights of authors and performers to the related rights holders at the same time. Strong policy arguments favoured such "breaks" of the author-centric copyright. Those policy arguments include(d) the fights against piracy, supporting investment and innovation. To the contrary, such a "break" is correctly refuted, where no strong policy arguments support the protection of non-human originators. Such a notable example is the lack of protection for the benefit or animals. This is best evidenced by the famous (or notorious) Monkey selfie case. There a US federal court refused to grant protection to photographs made by a black macaque. ${ }^{116}$ Several scholars base their policy considerations on this case to argue in favour

\footnotetext{
110 Article 27 and Article 15, respectively.

111 Bonadio / McDonagh (2020) 116.

112 Compare to Case C-5/08 - Infopaq International A/S v. Danske Dagblades Forening, Judgement of the Court (Fourth Chamber), 16 July 2009 (ECLI:EU:C:2009:465); Case C-145/10 - Eva-Maria Painer v. Standard Verlags GmbH and Others, Judgment of the Court (Third Chamber), 1 December 2011 (ECLI:EU:C:2011:798); Joined Cases C-403/08 and C-429/08 - Football Association Premier League Ltd and Others v. QC Leisure and Others, and Karen Murphy v Media Protection Services Ltd., Judgment of the Court (Grand Chamber), 4 October 2011 (ECLI:EU:C:2011:631); Case C-604/10 - Football Dataco Ltd and Others v. Yahoo! UK Ltd and Others, Judgment of the Court (Third Chamber), 1 March 2012 (ECLI:EU:C:2012:115); Case C-310/17 - Levola Hengelo BV v. Smilde Foods BV, Judgment of the Court (Grand Chamber), 13 November 2018 (ECLI:EU:C:2018:899); Case C-683/17 Cofemel - Sociedade de Vestuário SA v. G-Star Raw CV, Judgment of the Court (Third Chamber), 12 September 2019 (ECLI:EU:C:2019:721). See to the same effects: Case C-833/19 - SI, Brompton Bicycle Ltd. v. Chedech / Get2Get, Opinion of Advocate General M. Campos Sánchez-Bordona, 6 February 2020 (ECLI:EU:C:2020:79).

${ }^{113}$ Under this Supreme Court ruling from 1879, the copyright law only protects "the fruits of intellectual labor" that "are founded in the creative powers of the mind." See Trade-Mark Cases, 100 U.S. 82(1879), p. 94.

114 On the meaning and the historic development of authorship in the US copyright law see especially Samuelson (1986) 1197-1199.; Bridy (2012) 3-9.; Palace (2019) 226-231.; Gervais (2020b) 23-36.

115 Directive 2009/24/EC of the European Parliament and of the Council of 23 April 2009 on the legal protection of computer programs (Codified version), Article 2(1). Compare to Ballardini / He / Roos (2019) 123.

116 Naruto, et al. v. David John Slater, et al., 888 F.3d 418 (2018). Although the Ninth Circuit affirmed the lower court's ruling on the ground that the monkey had no standing to sue, but the ruling itself complies with the U.S. Copyright Office's most recent understanding of the concept of "author" as well. The Compendium of U.S. Copyright Office Practices declare that "The U.S. Copyright Office will register an original work of authorship, provided that the work was created by a human being. (...) Because copyright law is limited to "original intellectual conceptions of the author,' the Office will refuse to register a claim if it determines that a human being did not create the work." See: U.S.
} 
of an AI-copyright regime. ${ }^{117}$ This view is, however, superficial and totally misleading at the same time. Animals might execute cognitive tasks that might serve "communication purposes"; they however, never do such acts for "dissemination purposes". Animals do not aim to be treated as authors, do not fight for individual rights nor do they create for rewards and incentives. If we use the Naruto case as an analogy, it might be a better analogy against AI-copyright rather than in favour of it.

Shall AI be treated as a subject of authorship? ${ }^{118}$ Should we grant such status to algorithms even in the clear lack of any personality on their side? ${ }^{119}$ And finally, even if we grant e-personality to machines, shall that concept be an equivalent of the personality rights granted to humans?

I take the view that only humans can be authors in a copyright sense. ${ }^{120}$ As Christopher Buccafusco perfectly summarized: "[c]onstitutionally, copyright law requires authors; it cannot simply kill them off". ${ }^{121}$ Or as Guido Noto La Diega noted, "[t] he fully dehumanised production of authorial and entrepreneurial works requires either interpretative stretches or, better, a legislative reform that clarifies the crucial points of authorship and ownership of AI works". ${ }^{122}$ For the purposes of copyright protection there must be a human behind the machine, and authorship cannot be fully "de-romanticized"; ${ }^{23}$ or, as Josefien Vanherpe put it: "[c]reativity is hereby viewed as a quintessentially human faculty". ${ }^{24}$ And vice versa, the generation of any output is outside of the scope of copyright law, if there is no causal link between the output and any human behind the production of that output. If legislation intends to assign some form of IP protection to AI-generated outputs, that protection shall not be based on any "algorithmic authorship". These two words represent an irresolvable paradox.

\section{The threshold of originality}

Similarly to the concept of author, originality is not defined by international copyright norms. Nothing else than an open list of possible subject matters and a mere reference to "original works" in the Berne Convention, ${ }^{125}$ and the coverage of idea v. expression dichotomy by various treaties ${ }^{126}$ help countries to set the threshold of protection in their domestic copyright regimes.

\footnotetext{
Copyright Office (2017) §306. Later, the Compendium lists “[a] photograph taken by a monkey” as the \#1 example for expressions that are ineligible for registration in the lack of human authorship. See ibid. at §313.2.

117 On the Naruto case see Guadamuz (2016) 1-12.; Buccafusco (2016) 1274-1275.; Lambert (2017) 14-15.; Hristov (2017) 448-449.; Liu (2018) 61-65.; Yanisky-Ravid / Velez-Hernandez (2018) 49-50.; Ihalainen (2018) 726.

118 As Pamela Samuelson put it concisely: "[o]nly those stuck in the doctrinal mud could even think that computers could be 'authors'." See Samuelson (1986) 1200.

119 Denicola noted that "writings rather than authors are the more obvious starting point, and asking whether a computer can create a writing seems more pertinent than asking whether it can be an author". See Denicola (2016) 271.

${ }^{120}$ Deltorn / Macrez (2018) 8-9.

121 Buccafusco (2016) 1260.

122 Noto La Diega (2018) 106.

123 Craig / Kerr (2019) 30-37.

124 Vanherpe (2020) §19.

125 Compare to Berne Convention, Article 2(1) and (3). See further Ricketson (1991) 10.

126 See WIPO's Copyright Treaty, Article 2; TRIPS Agreement, Article 9(2).
} 
For long, the domestic variations of originality showed significant differences, ${ }^{127}$ ranging from the "sweat of the brow" doctrine in the USA ${ }^{128}$ through the British "skill, labour and judgment"129 or the Canadian "exercise of skill and judgment"" to the Continental European quest for "personal imprints" of the authors ${ }^{131}$ and the (strictest) German "Schöpfungshöhe" (level of creativity). ${ }^{132}$ In the last three decades, however, we have witnessed a global merger of the concept of originality. ${ }^{133}$ This "global entropy" is partially due to various concurring events/rulings in different countries/regions of the world. E.g. the United Kingdom accessed the European Economic Community (later the European Union) in 1973, and the EU directives have led to doctrinal changes to the topic of originality in the UK. ${ }^{134}$ The United States joined the Berne Convention in 1988 (as well as other multilateral treaties in the 1990s); and the Supreme Court of the United States quashed the "sweat of the brow" doctrine in its seminal Feist v. Rural ruling in $1991 .{ }^{135}$ In fact, the USA got closer to its European counterparts regarding the meaning of originality. ${ }^{136}$ The CJEU introduced a "common denominator" concept of the threshold of originality. This autonomous concept of EU law turned to be stricter than the British concept of "skill, labour and judgment", but was a clearly lower standard than the German "Schöpfungshöhe". ${ }^{137}$

It is also important that originality is closely connected to various other concepts of copyright law, and hence it cannot be discussed in an isolated way. All intentions to apply originality to emergent works requires the careful balancing of originality, authorship, ${ }^{138}$ subject matter ${ }^{139}$ and - in countries where it is (still) relevant - creativity. ${ }^{140}$

\footnotetext{
127 Gervais (1991) 634-640; Goldstein / Hugenholtz (2010) 189-194.

128 On the pre-Feist case law on originality see Bridy (2012) 15.

129 See especially Ladbroke v. William Hill [1964] All E.R. 465 at 469. Compare to Bently / Sherman (2009) 94-107.

${ }^{130} \mathrm{CCH}$ Canadian Ltd. v. Law Society of Upper Canada, Supreme Court of Canada, 2004 SCC 13.

131 Goldstein / Hugenholtz (2010) 190.

132 Schricker (1995) 41.

133 Gervais (2002) 949-981. See further Judge / Gervais (2009) 375-408.

134 Rahmatian (2019) 4-34.; Maggiore (2018) 389.

135 Feist Publications, Inc. v. Rural Telephone Service Co., 499 U.S. 340 (1991), p. 345. On the post-Feist meaning of originality in the USA see Ginsburg (1992) 338-388.; Guadamuz (2017) 180-183.; Yanisky-Ravid / Velez-Hernandez (2018) 22-31.; Gervais (2020b) 39-46.

136 " [T] $]$ he decision is closest to the aesthetic test: The Feist Court wants a living, breathing author; without one, there cannot be the 'originality' demanded. (...) Copyright Law in the United States is shifting toward the European model, but it is still entrapped in the ideology of its American past”. See Price / Pollack (1992) 717 and 720.

${ }^{137}$ Besides the case law of the CJEU listed in note 107 supra, on the concept of originality under EU law see e.g. Synodinou (2012) 93-113.; Rosati (2013); Leistner (2015) 626-630.; Pila / Torremans (2016) 271-284.; Guadamuz (2017) 177-180.; Bonadio / McDonagh / Arvidsson (2018) 666-669.; Margoni (2018) 5-8.; Ballardini / He / Roos (2019) 124-125.; Nägele / Apel (2020) 294.; Walter (2020) 3-5.; Kur (2020) 290-300.; Suthersanen / Mimler (2020) 573-575.

${ }^{138}$ E.g. the CJEU case law follows to interpret originality as the "author's own intellectual creation"; and the US Copyright Act expressly states that "original works of authorship fixed in any tangible medium of expression" are protected by the federal law. (Compare to U.S. Copyright Act, §101.)

139 The Berne or the Rome Convention allows for a flexible codification of protected subject matters. Article 2 of the Berne Convention provides an example for an open list (examples) of works, but Member States are free to introduce other categories or a closed list of protected works. Compare to the United Kingdom's Copyright, Designs and Patent Act, $\S 1$ and 3-8 and the United States' Copyright Act, §102. See further Bently / Sherman (2009) 58.; Goldstein / Hugenholtz (2010) 195.; Yanisky-Ravid (2017) 714-715.

140 Such a notable example is the US copyright law, where a "modicum of creativity" is a doctrinal element of originality. To the contrary, The Supreme Court of Canada expressly refuted the requirement of minimum level of creativity. See CCH Canadian Ltd. v. Law Society of Upper Canada (2004) para, 16 and 25.
} 
David Cropley's recent book on human creativity started with a simple statement: “[n]obody really knows what creativity is!"141 Unsurprisingly, AI-positivist researchers pay close attention to the concept of creativity to convince their readers that AI-generated outputs fulfil the requirements of originality. As Florian De Rouck put it, "[w]hether a computer can be creative is ultimately a philosophical question". ${ }^{142}$ Similarly, Tim W. Dornis argued that creativity might be viewed from the perspective of the process or the result; where "process creativity" focuses on the originator's creative choices, and "result creativity" focuses on the output's features. ${ }^{143}$ This second category might be the means to protect emergent works.

This logic is, however, flawed for at least a few reasons. First, as indicated above, creativity is not a prerequisite of protection in many countries, including the European Union. To the contrary, originality is generally fixed to authorship and subject matter, both of which are closely connected to humans and human achievements. Second, originality's "original premise" is much more personal and cultural than any utilitarian understanding, e.g. Dornis' "process creativity", would suggest. Indeed, as Neil Weinstock Netanel convincingly noted, copyright's "production function" is to provide "an incentive for creative expression on a wide array of political, social, and aesthetic issues, thus bolstering the discursive foundations for democratic culture and civic association". 144

The romantic concept of authorship (and the quest for geniuses in the process of creation) might be dead - but human-centric authorship is still alive. As Sam Ricketson put it: "[t]here [should] be some intellectual contribution above and beyond that of simple effort ('sweat of the brow')" for the purposes of copyright protection. ${ }^{145}$ Copyright law is not an investment protection scheme. ${ }^{146}$ The fact that some countries have entered a sharp "AI race" recently, ${ }^{147}$ does not legitimize the need for (urgent) protection of emergent works. ${ }^{148}$ Originality cannot be dehumanized, and cannot be lowered to cover non-human, algorithmic (mass) production of outputs as well - at least not without any good reason.

\section{Moral rights versus AI}

Finally, moral rights deserve close attention by both AI-pessimists and positivists. The main purpose of moral rights - e.g. the most well-known examples: the rights of paternity, integrity, first publication and withdrawal - is to build a strong personal relationship between the author and her work. ${ }^{149}$ In a truly metaphoric sense, moral rights intend to protect the author's "trademarks" in the copyright industry.

\footnotetext{
${ }^{141}$ Cropley (2019) 1. It shall be noted, however, that Cropley's book is not dedicated to copyright law, but to discuss creative human innovations across ten epochs of human history.

142 De Rouck (2019) 434. See further Rohner (2019) 62 and 66.

143 Dornis (2019) 1254-1255.

144 Netanel (1996) 288 and 347-351.

145 Ricketson (1991) 10.

146 Gervais (2020b) 41.

147 Hristov (2020) 2.

148 To the contrary, see Thampapillai (2019) 96-113.

149 Sundara Rajan (2011) 9.
} 
Anne Lauber-Rönsberg and Sven Hetmank noted that "[ $\mathrm{t}]$ oday, the emotional bond between author and work has been loosened". ${ }^{150}$ No doubt, moral rights - that are the manifestations of the Romantic concept of authorship - are dead in some sense in the $21^{\text {st }}$ century. Still, they work as "an indicator of [the work's] subject, reliability, and quality". ${ }^{151}$ Similarly, Michel Foucault believed that "the author's name is not simply an element in a discourse (...); it performs a certain role with regard to narrative discourse, assuring a classification function".

By their nature, moral rights are bound to the human originators of the protectable expressions, and as such, they are inherent obstacles to any argument in favour of AI-copyright. We shall put aside this fact for a second, and try to answer the following question: can AI exercise the rights treated to be moral (or personal)? More precisely: can an algorithm have a name that is connected to its output? Can an AI decide the time of first publication? Can it decide on the withdrawal of the content; and can it "believe" that its output is complete in its form, and no detrimental changes or modifications shall be made to the expression? The answer might be clearly affirmative. Indeed, as humbly indicated above, moral rights represent the "trademarks" of the creators of contents, and in an overly trade oriented IP world, algorithms might be able to exercise such rights with great effectiveness.

It is, however, a totally different question, whether algorithms can have any interests in those moral rights? Similarly to Daniel Gervais ' comment on the lack of interests for rewards and incentives by the $\mathrm{AI},{ }^{153}$ it is truly doubtful that machines need any enforceable rights to protect these moral oras they are more frequently called in the European droit d'auteur and Urheberrecht - personal interests. And this is undeniable because AI simply does not fit into the existing concept of moral rights, as algorithms have no "personality".

\section{Options of protection - and the reasons of their dysfunctionality}

In the previous chapter, I discussed five doctrinal elements of copyright law that are unfit to embrace emergent works at the moment. Unsurprisingly, this view of mine is far from accepted either in academia or in practice. Indeed, the summary report of AIPPI's 2019 annual world congress on "Copyright in artificially generated works" analysed the response of over 30 national groups to AIPPI's questionnaire. The report evidenced that significantly diverging views exist on the protectability of AI-generated outputs. ${ }^{154}$ It is worth the time to take a quick look at the available options regarding protectability.

The default (and, in my opinion, the correct ${ }^{155}$ ) answer to the challenges of emergent works is public domain. While some might argue that a public domain solution would lead to lost incentives, we shall agree with Victor Palace, who noted that "the artificial intelligence industry is likely to continue flourishing regardless of copyrights - as it has until now - because of the incentives inherent to the artificial intelligence industry". ${ }^{156}$ Others confirm that preserving the

${ }^{150}$ Lauber-Rönsberg / Hetmank (2019) 573.

${ }^{151}$ De Rouck (2019) 435.

152 Foucault (1984) 107.

${ }^{153}$ Compare to note 103 supra.

${ }^{154}$ Osha (2019). See further Bond (2019).

155 On the counterarguments to a public domain regime see Bonadio / McDonagh (2020) 132-133.

${ }^{156}$ Palace (2019) 239. 
unprotected nature of AI-generated outputs prioritize the community's interests over available knowledge, which could ultimately enhance cultural development, ${ }^{157}$ maybe also by fostering cooperation between AI and humans. ${ }^{158}$ An alternative approach to the public domain concept calls machine-enabled outputs "authorless". Under this concept, if the designer of the machine cannot claim sole authorship over the output/work; does not control the machine's executional process; and the designer and the user of the machine do not collaborate in real time (to create the output in question), the output shall become "authorless", and shall remain in the public domain. ${ }^{159}$

The "least intrusive" IP-oriented solution is the Japanese legislative proposal to introduce a "non-human-created IP" regime to cover AI-generated outputs, according to which "[r]ather than extending the copyright system, the policy body will look into a framework that handles works created by $\mathrm{AI}$ in a manner similar to trademarks, protecting them from unauthorized use through legislation prohibiting unfair competition", and "the plan is to grant protection only to properties that achieve a certain degree of popularity or otherwise hold market value, in light of AI-based systems' ability to create an enormous body of work in a short time". 160

The idea of a brand new "disseminators' right" - similarly to the one introduced by the EU Copyright Term Directive related to the publisher's right in the publication of previously unpublished works - also appeared in the scientific literature. ${ }^{161}$ Others discussed the application of the existing concepts of (the European Union's) database makers' sui generis regime ${ }^{162}$ or of the neighbouring rights to emergent works. ${ }^{163}$ Others expressly favoured the introduction of a brand new sui generis regime. ${ }^{164}$

A lot of authors paid close attention ${ }^{165}$ to the UK's - as well as New Zealand's, Ireland's, Hong Kong's, South Africa's and India's similar - fiction to grant protection to "humans behind the machine" regarding computer generated works. ${ }^{166}$

\footnotetext{
157 Compare to Yamamoto (2018) 10-15.; Kop (2020a) 24-29.

158 Palace (2019) 240.

159 Ginsburg / Budiardjo (2019) 453-454.

160 Segawa (2016). See further Ihalainen (2018) 727-728.; Kop (2020a) 7.

161 Ramalho (2017) 22.

${ }^{162}$ Noto La Diega (2018) 114.

163 Dornis (2019) 1260-1264.

164 Bonadio / McDonagh (2020) 133-136.

165 See e.g. Ricketson (1991) 28-30; Ramalho (2017) 17-18.; Maggiore (2018) 395-399.; Lauber-Rönsberg / Hetmank (2019) 574-575.; Kop (2020a) 7.; Gervais (2020b) 55-56.; Lambert (2017) 13-14.; Guadamuz (2017) 175-177.; Deltorn / Macrez (2018) 12-13.; Bonadio / McDonagh / Arvidsson (2018) 669-671.; Bonadio / McDonagh (2020) 119-124.

166 Compare to Copyright, Designs and Patents Act 1988, §9(3) ["[i] n the case of a literary, dramatic, musical or artistic work which is computer-generated, the author shall be taken to be the person by whom the arrangements necessary for the creation of the work are undertaken"] and $\S 178$ ["computer-generated", in relation to a work, means that the work is generated by computer in circumstances such that there is no human author of the work"]. See further Payen Components South Africa v. Bovic Gaskets (1996) 33 IPR 406 at 411, where the Supreme Court of South Africa differentiated between "computer-generated" and "computer-assisted" works. On an a contrario endorsement of this solution (that is the critique of the lack of similar norms and its consequences for the protectability of computer-generated works in Australia) see McCutcheon (2013a) 915-969.; McCutcheon (2013b) 46-102.; Selvadurai / Matulionyte (2020) 538.
} 
Many scholars discussed whether the work-made-for-hire doctrine could be tailored to effectively serve the interests of AI-employers; ${ }^{167}$ and so "the human behind the machine" can be rewarded for all past and future outputs of any machine. Others discussed - and immediately declared "undesirable or even impossible" - the reduction of the copyright term of protection. ${ }^{168}$ Some solicited for a combined acknowledgement of authorship and ownership interests over emergent works and a compulsory licensing of these outputs under Creative Commons licenses. ${ }^{169}$ Finally, a lot of emphasis has been put on the discussion of authorship and ownership interests (without any further restrictions) on programmers', software owners' and/or users' side; ${ }^{170}$ or even joint authorship for humans and AI. ${ }^{171}$

Some of these proposals simply lack merit or run against the mere logic of copyright (and civil) law; e.g. those related to the reduction of copyright term or the mandatory combination of authorship and Creative Commons licensing. Other ideas are based on the possibility of stretching existing concepts to cover the AI-industry. As database makers' sui generis protection or neighbouring rights regimes are based on significantly different policy purposes, and the exact norms offer insufficient flexibility to cover emergent works either, ${ }^{172}$ these proposals cannot generally be endorsed.

Similarly, irrespective of its fanciness, the tailored work-made-for-hire (or, more properly, "contents-generated-for-hire") doctrine lacks any doctrinal/philosophical basis, ${ }^{173}$ and it fails to meet all fundamental requirements of the (US) copyright law. First, such doctrine would over-reward the possible rights holders by protecting the unlimited outputs produced by the algorithm. ${ }^{174}$ Second, the prerequisites of "work", "author" or "employee" (the last two would require a "human worker") are fully missing in an AI-environment. ${ }^{175}$ Third, even under the work-made-for-hire concept the original work (the rights upon which are transferred to employees/commissioners) is (and must be) created by humans. The work-made-for-hire concept simply cannot be separated from the originalist premise of human authorship. Finally, any non-anthropocentric work-made-for-hire doctrine would clearly run against the spirit and the obligations under the Berne Convention. ${ }^{176}$

At least on its surface, the most promising option, the concept of "computer generated works", fails to meet the high expectations either. First, while it leaves enough space for manoeuvre, it fails to cover the widest range of AI-generated outputs. ${ }^{177}$ Second, this norm has triggered only a single

167 Compare to Hristov (2017) 445-447.; Yanisky-Ravid (2017) 707-718.

168 Lauber-Rönsberg / Hetmank (2019) 577.; Kop (2020a) 28.

169 Devarapalli (2018) 727-728.

170 Ralston (2005) 303-304.; Hristov (2017) 443-445.

171 Ralston (2005) 305-306; Grubow (2018) 387-423.

172 Compare to Lauber-Rönsberg / Hetmank (2019) 575.; Rohner (2019) 81.; Kop (2020a) 8. Indeed, neighbouring rights tend to be obsolete, "outdated and inherently unbalanced". See Hugenholtz (2019) 1006-1011.

173 "Here, the risk is that a repeated use of the fiction that treats an AI output as human work made for hire will chip away at the legal distinction between humans and AIs and ultimately undermine the ontological category of "author" as a particular sort of relational, discursive social practice”. See Craig / Kerr (2019) 22.

174 Palace (2019) 236.

175 On these counter-arguments see e.g. Bridy (2012) 26-27.; Gervais (2020b) 46-48.; Bonadio / McDonagh (2020) 118-119.

176 Ricketson (1991) 28.

177 Noto La Diega (2018) 106. 
decision in a three decades long timespan in its birthplace, the UK, ${ }^{178}$ which perfectly mirrors its limited success in real life. Third, recalling Lionel Bently and Brad Sherman's opinion, "these changes were useful insofar as they clarified that creations generated by a computer could be classified as works, they said nothing about how the originality of such works was to be determined". ${ }^{179}$

New sui generis regimes might look practical in regulating an "emerging field" of IP, however, they are not without faults either. On the one hand, due to their tailor-made nature, there might be a significant disagreement over the acceptance of the exact norms on a multilateral level. On the other hand, the database makers' sui generis rights have also triggered serious criticism. E.g. Julia Johnson correctly noted that ,[i]n 2002, the World Intellectual Property Organization (WIPO) published a study identifying five concerns with the sui generis approach to database protection: that it could remove information from the public domain; create perpetual monopolies; harm the free flow of information; stifle the development of software and information systems; and hamper access to intellectual property in the developing world". ${ }^{180}$ We shall be ready to address such critical notes, too, in case countries introduce any sui generis regime for the benefit of AI-investors.

\section{Conclusion}

Michel Foucault, in his discussion on what the concept of author might mean, quoted (and criticized) Samuel Beckett's famous question: "what does it matter who is speaking"? ${ }^{181}$ Foucault himself argued that "it does not seem necessary that the author function remain constant in form, complexity, and even in existence. I think that, as our society changes, at the very moment when it is in the process of changing, the author function will disappear". ${ }^{182}$ AI-positivists usually echo this opinion and believe that "[i]f the copyright regime did not apply, such works could arguably cause market failures in the absence of other (legal) mechanisms which ensure substantively similar protection with appropriate public interest safeguards". ${ }^{183}$ Or, as Toby Bond and Sarah Blair questioned it, "[s]hould copyright only reward acts of truly human cognition or does it play a more utilitarian role in society, encouraging the production and distribution of new works irrespective of the manner in which they were created?"184

With due respect, this paper respectfully disagrees with the opinions noted above. I highlighted those fundamental arguments that support an AI-pessimistic view, or, being more terminologically pessimistic, the reasons why the current copyright regime (without being unnecessarily hacked) cannot cover emergent works. Some visionary opinions might be quoted to support this position. Sam Ricketson noted three decades ago that "[p]eople, rather than machines, have always been the object of the [Berne] Convention, and, from the point of view of principle, doctrine and practicality, this object should continue to be upheld". ${ }^{185}$ Lev Grossman put it in his seminal article

\footnotetext{
178 Nova Productions Ltd. v. Mazooma Games Ltd. [2006] EWHC 24 (Ch). Compare to Dickenson / Morgan / Clark (2017) 458-459.; Bond - Blair (2019) 423.

179 Bently / Sherman (2009) 107.

180 Johnson (2015) 256.

181 Foucault (1984) 101.

182 Ibid. at 119.

183 De Rouck (2019) 435.

184 Bond / Blair (2019) 423.

185 Ricketson (1991) 37. See further Ginsburg (2018) 131.
} 
on singularity, "[c]reating a work of art is one of those activities we reserve for humans and humans only. It's an act of self-expression; you're not supposed to be able to do it if you don't have a self". ${ }^{186}$ Indeed, "allocating the copyright to the artificial intelligence would result in overwhelming and unnecessary legal uncertainty, and it would be contrary to the goal of the Patent and Copyright Clause". ${ }^{187}$ This might be true in Europe as well, even though we have no equivalent to the IP Clause of the United States Constitution. Finally, and maybe most importantly, Daniel Gervais convincingly summarized the ultimate goal of copyright law: "both art in myriad forms and quality journalism have had and should continue to have a role in helping humans understand and better their world. (...) [H] uman progress should serve as a normative guidepost". 188

In sum, this paper takes the view that, on the one hand, copyright law is a fiction, a legal manifestation of a complex (socio-cultural and economic), fluid and constantly changing set of interests. Unless comprehensive and convincing social, cultural and economic (empirical) evidences exist (or come into existence) to the opposite, the lack of justifications, sound policy arguments and doctrinal clarity shall bar the introduction of any copyright protection for emergent works. ${ }^{189}$ A rare example for empirical evidences is a paper by Kalin Hristov. His questionnaire analysing the response of fifty-seven AI scientists, tech policy experts and copyright scholars also concluded that

"half of participants believe that the US copyright system is not adequately prepared for a future influx of AI-produced works. Respondents, however, fail to reach a resounding consensus on what changes should be implemented by the US Copyright Office. The divided nature of expert opinion and the limited data available to researchers studying intellectual property protection of AI works indicates the need for future research on the topic."190

As long as we are uncertain that the society in general, and human progress (especially culture) in specific would benefit from an AI-copyright regime, rather than only a few stakeholders involved in AI-research, we favour not to regulate at all. We shall agree with Axel Walz, who noted that ,[r] egulation, though, is not the only possible, and in many cases may not even be the best approach to retain control over AI". ${ }^{191}$ Likewise, Daniel Schönberger took the view that the "claims for legislative actions are not convincing". ${ }^{192}$ I believe that the wisest decision would be to follow a wait-and-see approach, and check whether licensing of AI-generated outputs (not as a work, but as information or data) necessitates any intervention - either pro or contra the interests of "creators" or AI-investors.

Admittedly, this summary opinion fails to answer an important question. Namely, will the copyright protection of AI-generated outputs ever become a reality? We shall admit that it would be unwise to regret or refuse this possibility - especially as copyright law is a fiction. Finding an appropriate incentive ${ }^{193}$ or policy ${ }^{194}$ for, as well as the appropriate form of the protection and the

186 Grossman (2011).

187 Palace (2019) 234.

188 Gervais (2020b) 9.

189 Compare to Ginsburg / Budiardjo (2019) 455-456.; Vanherpe (2020) §23.

${ }^{190}$ Hristov (2020) 13.

191 Walz (2017) 759.

192 Schönberger (2017) 158. See in greater details ibid. at p. 159-160.

193 Compare to Ballardini / He / Roos (2019) 130-134.

194 Manuel Desantes Real took the view that AI can be the flagship of the Fourth industrial revolution, where the 
detailed and balanced set of rules (maybe one of the many options introduced above or a mixture of them) does not seem to be impossible at all. At the moment, however, the protectability of emergent works is a less acute copyright question than whether the use of algorithms in data analysis runs against existing copyrights (including database makers' sui generis protection), or whether AI (creators, investors or users) can rely on any limitation or exception. ${ }^{195}$ Indeed, it looks a balance compromise to apply limitations or exceptions for the benefit of AI in order to support effective machine learning activities, rather than envisaging any copyright protection for the AI-generated outputs. Similarly, it is still an open question whether automated (algorithmic) enforcement of copyright is desirable or acceptable, ${ }^{196}$ or, ultimately, whether it leads to modern (digital) copyright censorship. ${ }^{197}$

We shall agree with James Grimmelmann that “[c]opyright law doesn't recognize computer programs as authors, and it shouldn't. Some day it might make sense to, but if that day ever comes, copyright will be the least of our concerns". ${ }^{198}$ The inferiority - or less timely nature - of protection of emergent works is also visible from many policy reports of national and intergovernmental AI-policies that tend to put greater emphasis on the intertwined notions of trust $^{199}$ and transparency in, ${ }^{200}$ as well as accountability of ${ }^{201}$ AI. E.g. copyright law played no significant role in the European Union's policy documents since the Civil Law Rules of Robotics was finally abandoned. Both the European Strategy for AI of 2018, ${ }^{202}$ and, most recently, the White Paper 2020 have sidestepped this issue. ${ }^{203}$ Indeed, the White Paper 2020 laid down the foundations of a human-centric and ethical, trustworthy regime of AI regulations that provide for clear norms on the responsibility for as well as the guarantees of the safety of AI research and outputs. The White Paper declared a key prerequisite of any such system of rules that outputs are overseen by humans, and European values and other existing rules are respected. The U.S. Government's AI Initiative expressed its intent to secure the economic leadership of the United States in the field of AI, on the one hand, and listed key policies and practices e.g. investing in AI research and development; unleashing AI resources; removing barriers to AI innovation; training an AI-ready workforce; promoting an international environment supportive of American AI innovation; and embracing trustworthy AI for government services and missions. ${ }^{204}$ Neither the

available approaches to AI and IP might range from stagnation to adaptation, disruption or reinvention. Under this opinion, AI-pessimism is not a real approach. See Desantes Real (2020) 3-27.

195 Sobel (2017) 45-97.; Schönberger (2018) 160-172.; Binctin (2019) 5-32.; Rosati (2019) 198-217.; Chiou (2019) 401-411.; Kop (2020b) 9-11.; Lemley / Casey (2020); Bonadio / McDonagh (2020) 126-131.; Meys (2020) 457-473.; Selvadurai / Matulionyte (2020) 539-542.; Flynn / Geiger / Quintais / Margoni / Sag / Guibault / Carroll (2020) 393-398.

${ }_{196}$ Compare to Elkin-Koren (2017) 1082-1100.; Grosse Ruse-Khan (2020) 16.

197 Senftleben (2020) 339-340.

198 Grimmelmann (2016) 403.

199 On trust in AI see e.g. Rohner (2019) 78.; Kop (2020a) 29-31.; McLeod Blythe (2020) 119-125. The reliability of $\mathrm{AI}$ algorithms is a crucial prerequisite of their widespread use. As long as they generate a significant amount of false positives in e.g. criminal investigations, they shall only be applied with cautions. As the New York Times reported, "[i]n 2019, algorithms from both companies were included in a federal study of over 100 facial recognition systems that found they were biased, falsely identifying African-American and Asian faces 10 times to 100 times more than Caucasian faces". See: Hill (2020).

${ }^{200}$ On transparency in AI see e.g. Larsson / Heintz (2019) 1-16.

${ }^{201}$ On accountability of AI see e.g. Bandy / Diakopoulos (2020) 36-47.; Nahmias / Perel (2020) 1-54.

${ }^{202}$ Artificial Intelligence for Europe, $\operatorname{COM}(2018) 237$ final. Compare to Opitz (2018) 28-30.

${ }^{203}$ White Paper on Artificial Intelligence, $\operatorname{COM}(2020) 65$ final (2020).

${ }^{204}$ American Artificial Intelligence Initiative (2020). 
European, nor the American goals demand any strong IPR regime for the benefit of AI-investors or algorithms themselves. ${ }^{205}$

Nevertheless, legislative proposals might be on the horizon soon. The WIPO has launched a public consultation on AI and IP. As a part of that, WIPO has prepared a draft and a revised Issues Paper on IP Policy and AI, and has also completed two rounds of "conversations", ${ }^{206}$ while planning the third round of those conversations for November $2020{ }^{207}$ Indeed, it might be the wisest option, if WIPO takes the lead in solving the necessarily global tensions surrounding the IP/copyright protection of AI-generated outputs.

The European Parliament, unlike the European Commission, seems to be more receptive to the idea of AI-copyright as well. On the one hand, the "Draft Report on intellectual property rights for the development of artificial intelligence technologies", published on April 24, 2020, recommended to side-line the hurdles posed by originality (and the personal touch) by relying on "the creative result rather than the creative process". ${ }^{208}$ On the other hand, the report also intended to focus on the "human behind the machine", and proposed that

"an assessment should be undertaken of the advisability of granting copyright to such a 'creative work' to the natural person who prepares and publishes it lawfully, provided that the designer(s) of the underlying technology has/have not opposed such use. This reasoning would be in line with the European system of protection of 'works data'; such data may be exploited as part of the data used to train AI technologies which can then generate secondary creations, including for commercial purposes, provided that the right to such use has not been expressly reserved by their rightholders". 209

In sum, the European Parliament's (current) position opens the door for some kind of AI-positivistic legislation. ${ }^{210}$ Whether such system would truly favour human culture and the copyright ecosystem in general, is still unclear. We shall therefore keep a watchful eye on the proposed assessment of the European Parliament.

\section{Bibliography}

Alba (2019) = Davey Alba: Facebook Discovers Fakes That Show Evolution of Disinformation, The New York Times, December 20, 2019 (https://www.nytimes.com/2019/12/20/business/facebook-ai-generated-profiles.html)

Alexander / Gómez-Arestegui (2016) = Isabella Alexander / H. Tomás Gómez-Arestegui (Eds.): Research Handbook on the History of Copyright Law, Edward Elgar, Cheltenham, 2016

${ }^{205}$ The Ad Hoc Committee on Artificial Intelligence, established by the Committee of Ministers of the Council of Europe, originally expected to report on the human rights, democracy and the rule of law aspects of AI by March 2020, however, due to the COVID-19 epidemic, the completion of the report is postponed. See CAHAI Third Meeting (2020).

${ }^{206}$ I had the privilege to intervene on the second conversation, held virtually between July 7-9, 2020. The full text of my intervention is available here: Mezei (2020).

207 Artificial Intelligence Intellectual Property Policy (https://www.wipo.int/about-ip/en/artificial_intelligence/policy.html).

${ }^{208}$ Séjourné (2020). This proposal is in compliance with "process creativity" and "result creativity" distinguished by Tim W. Dornis. Compare to note 142 supra.

${ }^{209}$ Draft Report (2020/2015(INI)) 9.

${ }^{210}$ Not all are enthusiastic for such regulation. Some have criticized the usefulness of EU's legislative preparations, either for the lack of transparency of the discussions, the vagueness of proposals, or the slowness of legislation, See: Kelly (2020). 
Alpeyev (2018) = Pavel Alpeyev: SoftBank's Next Robot After Pepper Skips Chit Chat, Mops Floors, Bloomberg, November 19 ,

(https://www.bloomberg.com/news/articles/2018-11-19/softbank-s-next-robot-after-pepper-skips-chit-chat-mopsfloors)

American Artificial Intelligence Initiative (2020) $=$ The White House Office of Science and Technology Policy: American Artificial Intelligence Initiative: Year One Annual Report, February 2020 (https://www.whitehouse.gov/wp-content/uploads/2020/02/American-AI-Initiative-One-Year-Annual-Report.pdf )

Anderson (2001) = Mark K. Anderson: 'Aaron': Art From the Machine, WIRED, May 12, 2001 (https://www.wired.com/2001/05/aaron-art-from-the-machine/)

Artificial Intelligence for Europe, $\operatorname{COM(2018)~} 237$ final = Communication from the Commission to the European Parliament, the European Council, the Council, the European Economic and Social Committee and the Committee of the Regions - Artificial Intelligence for Europe, Brussels, 25.4.2018, $\operatorname{COM}(2018) 237$ final (https://ec.europa.eu/transparency/regdoc/rep/1/2018/EN/COM-2018-237-F1-EN-MAIN-PART-1.PDF)

Atabekov / Yastrebov (2018) = Atabek Atabekov / Oleg Yastrebov: Legal Status of Artificial Intelligence Across Countries: Legislation on the Move, European Research Studies Journal, Issue 4/2018, p. 774-782.

Bahr (2020) = Sarah Bahr: The Star of This \$70 Million Sci-Fi Film Is a Robot, The New York Times, July 24, 2020 (https://www.nytimes.com/2020/07/24/movies/humanoid-robot-actor.html)

Bailey (2020) = Jason Bailey: Can Machine Learning Predict the Price of Art at Auction?, Harvard Data Science Review, April 30, 2020 (https://hdsr.mitpress.mit.edu/pub/1vdc2z91/release/1)

Ball (2012) = Philip Ball: Iamus, classical music's computer composer, live from Malaga, The Guardian, July 1, 2012 (https://www.theguardian.com/music/2012/jul/01/iamus-computer-composes-classical-music)

Ballardini / He / Roos (2019) = Rosa Maria Ballardini / Kan He / Teemu Roos: AI-Generated Content: Authorship and Inventorship in the Age of Artificial Intelligence. In: Taina Pihlajarinne / Juha Vesala / Olli Honkkila: Online Distribution of Content in the EU, Edward Elgar, Cheltenham, 2019, p. 117-135.

Bandy / Diakopoulos (2020) = Jack Bandy / Nicholas Diakopoulos: Auditing News Curation Systems: A Case Study Examining Algorithmic and Editorial Logic in Apple News, Proceedings of the Fourteenth International AAAI Conference on Web and Social Media (ICWSM 2020), 2020, p. 36-47.

Barletta (2001) = Barbara A. Barletta: The Origins of the Greek Architectural Orders, Cambridge University Press, New York, 2001

Beckett (2015) = Stephen Beckett: Robo-journalism: How a Computer Describes a Sports Match, BBC, September 12, 2015 (https://www.bbc.com/news/technology-34204052)

Beneke / Mackenrodt (2019) = Francisco Beneke / Mark-Oliver Mackenrodt: Artificial Intelligence and Collusion, International Review of Intellectual Property and Competition Law, Issue 1/2019, p. 109-134.

Bennett / Daly (2020) = Belinda Bennett / Angela Daly: Recognising Rights for Robots: Can We? Will We? Should We?, Law, Innovation and Technology, Issue 1/2020, p. 60-80.

Bently / Sherman (2009) = Lionel Bently / Brad Sherman: Intellectual Property Law, Third Edition, Oxford University Press, New York, 2009

Binctin (2019) = Nicolas Binctin: TDM: A Challenge for Artificial Intelligence, R.I.D.A. - Revue Internationale du Droit d'Auteur, October 2019, p. 5-32.

Bonadio / McDonagh (2020) = Enrico Bonadio / Luke McDonagh: Artificial Intelligence as Producer and Consumer of Copyright Works: Evaluating the Consequences of Algorithmic Creativity, Intellectual Property Quarterly, Issue 2/2020, p. 112-137.

Bonadio / McDonagh / Arvidsson (2018) = Enrico Bonadio / Luke McDonagh / Christopher Arvidsson: Intellectual Property Aspects of Robotics, European Journal of Risk Regulation, Issue 4/2018, p. 655-676.

Bond (2019) = Toby Bond: AIPPI Congress Report 4: Copyright in AI Generated Works, The IPKat, September 27 , 2019 (http://ipkitten.blogspot.com/2019/09/aippi-congress-report-4-copyright-in-ai.html)

Bond / Blair (2019) = Toby Bond / Sarah Blair: Artificial Intelligence \& copyright: Section 9(3) or authorship without an author, Journal of Intellectual Property Law and Practice, Issue 6/2019, p. 423.

Boxall (2019) = Andy Boxall: Huawei's A.I. has finished Schubert's Unfinished Symphony, and we've heard it, Digital Trends, February 6, 2019 (https://www.digitaltrends.com/mobile/huawei-ai-unfinished-symphony/)

Boyden (2016) = Bruce E. Boyden: Emergent Works, Columbia-VLA Journal of Law \& the Arts, Issue 3/2016, p. 377-394.

Bracha (2016) = Oren Bracha: United States Copyright, 1672-1909. In: Alexander / Gómez-Arestegui (2016) 335-371.

Bridy (2012) = Annemarie Bridy: Coding Creativity: Copyright and the Artificially Intelligent Author, Stanford Technology Law Review, 2012, p. 1-28. 
Bringsjord / Ferrucci (2000) = Selmer Bringsjord / David Ferrucci: Artificial Intelligence and Literary Creativity: Inside the Mind of BRUTUS, a Storytelling Machine, Lawrence Erlbaum Associates, Mahwah, 2000

Broad $(2020)=$ William J. Broad: A.I. Versus the Coronavirus, The New York Times, March 26, 2020 (https://www.nytimes.com/2020/03/26/science/ai-versus-the-coronavirus.html)

Buccasfusco (2016) = Christopher Buccafusco: A Theory of Copyright Authorship, Virginia Law Review, 2016, p. 1229-1295.

CAHAI Third Meeting (2020) = Ad Hoc Committee on Artificial Intelligence (CAHAI), Third Meeting, 27 March 2020, CAHAI-BU(2020)REP2, $\quad$ Strasbourg, $\quad$ April $\quad 7, \quad 2020$ (https://rm.coe.int/cahai-bu-2020-rep2-eng-07042020-final-/16809e2b4f)

Carey (2020) = Benedict Carey: Can an Algorithm Predict the Pandemic's Next Moves?, The New York Times, July 2, 2020 (https://www.nytimes.com/2020/07/02/health/santillana-coronavirus-model-forecast.html)

Castets-Renard (2020) = Céline Castets-Renard: The Intersection Between AI and IP: Conflict or Complementarity?, IIC - International Review of Intellectual Property and Competition Law, Issue 2/2020, p. 141-143.

Chiou (2020) = Theodoros Chiou: Copyright Lessons on Machine Learning: What Impact on Algorithmic Art?, JIPITEC - Journal of Intellectual Property, Information Technology and E-Commerce Law, Issue 3/2019, p. $398-411$.

Cohn (2018) = Gabe Cohn: AI Art at Christie's Sells for \$432,500, The New York Times, October 25, 2018 (https://www.nytimes.com/2018/10/25/arts/design/ai-art-sold-christies.html)

Corrales / Fenwick / Forgó (2018) = Marcelo Corrales / Mark Fenwick / Nikolaus Forgó (Eds.): Robotics, AI and the Future of Law, Springer, Singapore, 2018

Craig / Kerr (2019) = Carys Craig / Ian Kerr: The Death of the AI Author, Osgoode Legal Studies Research Paper, March 25, 2019, p. 1-42. (https://ssrn.com/abstract=3374951)

Cropley (2019) = David H. Cropley: Homo Problematis Solvendis - Problem-solving Man, A History of Human Creativity, Springer Nature Singapore, Singapore, 2019

Cross (2020) = Tim Cross: An Understanding of AI's Limitations Is Starting to Sink In, The Economist, June 11, 2020 (https://www.economist.com/technology-quarterly/2020/06/11/an-understanding-of-ais-limitations-is-starting-tosink-in)

De Rouck (2019) = Florian De Rouck: Moral rights \& AI environments: the unique bond between intelligent agents and their creations, Gewerblicher Rechtsschutz und Urheberrecht Internationaler Teil, Issue 4/2019, p. 432-436.

Del Mar / Twining (2015) = Maksymilian Del Mar / William Twining (Eds.): Legal Fictions in Theory and Practice, Springer, Cham, 2015

Deltorn / Macrez (2018) = Jean-Marc Deltorn / Franck Macrez: Authorship in the Age of Machine Learning and Artificial Intelligence, Centre for International Intellectual Property Studies (CEIPI) Research Paper No. 2018-10, August 1, 2018, p. 1-25.

Denicola (2016) $=$ Robert C. Denicola: Ex Machina: Copyright Protection for Computer-Generated Works, Rutgers University Law Review, 2016, p. 251-287.

Desantes Real (2020) = Manuel Desantes Real: The Disruptive Nature of the So Called Fourth Industrial Revolution for Intellectual Property: Moving Societal Changes from Linear to Exponential. In: Christopher Heath / Anselm Kamperman Sanders / Anke Moerland (Eds.): Intellectual Property Law and the Fourth Industrial Revolution, Wolters Kluwer, Alphen aan den Rijn, 2020, p. 3-27.

Dettling / Krüger (2019) = Heinz-Uwe Dettling / Stefan Krüger: Erste Schritte im Recht der Künstlichen Intelligenz Entwurf der „Ethik-Leitlinien für eine vertrauenswürdige KI”, Multimedia und Recht, Heft 4/2019, p. 211-217.

Devarapalli (2018) $=$ Pratap Devarapalli: Machine Learning to Machine Owning: Redefining the Copyright Ownership from the Perspective of Australian, US, UK and EU Law, European Intellectual Property Review, Issue 11/2018, p. $722-728$.

Dickenson / Morgan / Clark (2017) = Julia Dickenson / Alex Morgan / Birgit Clark: Creative Machines: Ownership of Copyright in Content Created by Artificial Intelligence Applications, European Intellectual Property Review, Issue 8/2017, p. 457-460.

Dornis $(2019)=$ Tim W. Dornis: Der Schutz künstlicher Kreativität im Immaterialgüterrecht, Gewerblicher Rechtsschutz und Urheberrecht, Issue 12/2019, p. 1252-1264.

Dreyfuss $(2020)=$ Rochelle C. Dreyfuss: The Challenges Facing IP Systems: Researching for the Future. In: Peter Drahos / Gustavo Ghidini / Hanns Ullrich (Ed.): Kritika: Essays on Intellectual Property - Volume 4, Edward Elgar, Cheltenham, 2020, p. 1-46.

Elkin-Koren (2017) = Niva Elkin-Koren: Fair Use by Design, UCLA Law Review, 2017, p. 1082-1100.

Featherstone (2017) = Emma Featherstone: Introducing the Next Generation of Music Makers, The Guardian, August 29 , 
(https://www.theguardian.com/small-business-network/2017/aug/29/computer-write-music-jukedeck-artificial-int elligence)

Fenwick / Vermeulen / Corrales (2018) = Mark Fenwick / Erik P. M. Vermeulen / Marcelo Corrales: Business and Regulatory Responses to Artificial Intelligence: Dynamic Regulation, Innovation Ecosystems and the Strategic Management of Disruptive Technology. In: Corrales/Fenwick/Forgó (2018) 81-103.

Fildes (2020) = Nic Fildes: When AI Takes on Eurovision: Can a Computer Write a Hit Song?, ArsTechnica, May 11, 2020 (https://arstechnica.com/gaming/2020/05/when-ai-takes-on-eurovision-can-a-computer-write-a-hit-song/)

Fisher (2001) = William Fisher: Theories of Intellectual Property. In: Stephen Munzer (Ed.): New Essays in the Legal and Political Theory of Property, Cambridge University Press, New York, 2001, p. 168-199.

Flynn / Geiger / Quintais / Margoni / Sag / Guibault / Carroll (2020) = Sean Flynn / Christophe Geiger / João Pedro Quintais / Thomas Margoni / Matthew Sag / Lucie Guibault / Michael Carroll: Implementing User Rights for Research in the Field of Artificial Intelligence: A Call for International Action, European Intellectual Property Review, Issue 7/2020, p. 393-398.

Foucault $(1984)=$ Michel Foucault: What Is an Author? In: Paul Rabinow (Ed.): The Foucault Reader, Pantheon Books, New York, 1984, p. 101-120.

Fuller (1967) = Lon L. Fuller: Legal Fictions, Stanford University Press, Stanford, 1967

Gadd (2016) = Ian Gadd: The Stationers' Company in England Before 1710. In: Alexander / Gómez-Arestegui (2016) 81-95.

Garde $(2018)$ = Tanuja Garde: Artificial Intelligence and Induced Infringement, Gewerblicher Rechtsschutz und Urheberrecht Internationaler Teil, Issue 12/2018, p. 1132-1138.

Gervais $(1991)$ = Daniel J. Gervais: The Protection Under International Copyright Law of Works Created with or by Computers, IIC - International Review of Intellectual Property and Competition Law, Issue 5/1991, p. 628-654.

Gervais (2002) = Daniel J. Gervais: Feist Goes Global: A Comparative Analysis of the Notion of Originality in Copyright Law, Journal of the Copyright Society U.S.A., Summer 2002, p. 949-981.

Gervais $(2020 \mathrm{a})=$ Daniel Gervais: Is Intellectual Property Law Ready for Artificial Intelligence?, GRUR International, Issue 2/2020, p. 117-118.

Gervais (2020b) = Daniel Gervais: The Machine as Author, Iowa Law Review, 2020: p. 1-61. (forthcoming)

Ginsburg (1990) = Jane C. Ginsburg: A Tale of Two Copyrights: Literary Property in Revolutionary France and America, Tulane Law Review, Issue 5/1990, p. 991-1031.

Ginsburg (1992) = Jane C. Ginsburg: No "Sweat"? Copyright and Other Protection of Works of Information after Feist v. Rural Telephone, Columbia Law Review, 1992, p. 338-388.

Ginsburg (2016) = Jane Ginsburg: Proto-Property in Literary and Artistic Works: Sixteenth-Century Papal Printing Privileges. In: Alexander / Gómez-Arestegui (2016) 237-267.

Ginsburg (2018) = Jane C. Ginsburg: People Not Machines: Authorship and What It Means in the Berne Convention, IIC - International Review of Intellectual Property and Competition Law, Issue 2/2018, p. 131-135.

Ginsburg / Budiardjo (2019) = Jane C. Ginsburg / Luke Ali Budiardjo: Authors and Machines, Berkeley Technology Law Journal, 2019, p. 343-456.

Gleick (2011) = James Gleick: The Information - A History, a Theory, a Flood, Vintage Books, New York, 2011

Goldstein - Hugenholtz (2010) = Paul Goldstein - Bernt Hugenholtz: International Copyright - Principles, Law, and Practice, Second Edition, Oxford University Press, New York, 2010

Grady (2019) = Denise Grady: A.I. Comes to the Operating Room, The New York Times, December 13, 2019 (https://www.nytimes.com/2020/01/06/health/artificial-intelligence-brain-cancer.html)

Grimmelmann (2016) = James Grimmelmann: There's No Such Thing as a Computer-Authored Work - And It's a Good Thing, Too, Columbia Journal of Law \& the Arts, Issue 3/2016, p. 403-416.

Grosse Ruse-Khan (2020) = Henning Grosse Ruse-Khan: Automated Copyright Enforcement Online: From Blocking to Monetization of User-Generated Content, University of Cambridge Faculty of Law Legal Studies Research Paper Series, Paper no. 8/2020, March 2020, p. 1-18. (https://ssrn.com/abstract=3565071)

Grossman (2011) = Lev Grossman: 2045: The Year Man Becomes Immortal, Time Magazine, February 10, 2011 (http://content.time.com/time/magazine/article/0,9171,2048299,00.html)

Grubow (2018) = Jared Vasconcellos Grubow: O.K. Computer: The Devolution of Human Creativity and Granting Musical Copyrights to Artificially Intelligent Joint Authors, Cardozo Law Review, 2018, p. 387-423.

Guadamuz (2016) = Andres Guadamuz: The Monkey Selfie: Copyright Lessons for Originality in Photographs and Internet Jurisdiction, Internet Policy Review, Issue 1/2016, p. 1-12.

Guadamuz (2017) = Andres Guadamuz: Do Androids Dream of Electric Copyright? Comparative Analysis of Originality in Artificial Intelligence Generated Works, Intellectual Property Quarterly, Issue 2/2017, p. 169-186. 
Haigney (2019) = Sophie Haigney: Wondering Who Did That Painting? There's an App (or Two) for That, The New York Times, September 11, 2019 (https://www.nytimes.com/2019/09/11/arts/design/smartphone-art-app.html)

Hao (2019) = Karen Hao: OpenAI has released the largest version yet of its fake-news-spewing AI, MIT Technology Review, August 29, 2019 (https://www.technologyreview.com/s/614237/openai-released-its-fake-news-ai-gpt-2/)

He (2019) = Tianxiang He: The Sentimental Fools and the Fictitious Authors: Rethinking the Copyright Issues of AI-generated Contents in China, Asia Pacific Law Review, Issue 2/2019, p. 218-238.

High-Level Expert Group on Artificial Intelligence (2019) = High-Level Expert Group on Artificial Intelligence: A Definition of AI: Main Capabilities and Disciplines, 8 April 2019 (https://www.kowi.de/Portaldata/2/Resources/fp/Artificial-Intelligence-Definition.pdf)

Hill $(2020)=$ Kashmir Hill: Wrongfully Accused by an Algorithm, The New York Times, June 24, 2020 (https://www.nytimes.com/2020/06/24/technology/facial-recognition-arrest.html)

Horseman (2020) = Jeff Horseman: World premiere in November: Computer completes Beethoven's 10th Symphony, $\begin{array}{lllll}\text { The News } & \text { Mansion, } & 30, & \end{array}$ (https://www.archyde.com/world-premiere-in-november-computer-completes-beethovens-10th-symphony/)

Hristov (2017) = Kalin Hristov: Artificial Intelligence and the Copyright Dilemma, IDEA, Issue 3/2017, p. 431-454.

Hristov (2020) = Kalin Hristov: Artificial Intelligence and the Copyright Survey, Journal of Science Policy \& Governance, Issue 1/2020, p. 1-18.

Hugenholtz $(2019)=$ P. Bernt Hugenholtz: Neighbouring Rights Are Obsolete, IIC - International Review of Intellectual Property and Competition Law, Issue 8/2019, p. 1006-1011.

Huggler (2019) = Justin Huggler: Computer is set to complete Beethoven's unfinished symphony, The Telegraph, December 13 , 2019 (https://www.telegraph.co.uk/news/2019/12/13/computer-set-complete-beethovens-unfinished-symphony/)

Ihalainen (2018) = Jani Ihalainen: Computer Creativity: Artificial Intelligence and Copyright, Journal of Intellectual Property Law and Practice, Issue 9/2018, p. 724-728.

Johnson (1997) George Johnson: Undiscovered Bach? No, a Computer Wrote It, The New York Times, November 11, 1997 (https://www.nytimes.com/1997/11/11/science/undiscovered-bach-no-a-computer-wrote-it.html)

Johnson (2015) = Julia Johnson: Database Protection a Reality? How the Professional and Fantasy Sporting World Could Benefit from a Sui Generis Intellectual Property Right, Intellectual Property Journal, 2015, p. 237-256.

Judge / Gervais (2009) = Elizabeth F. Judge / Daniel Gervais: Of Silos and Constellations: Comparing Notions of Originality in Copyright Law, Cardozo Arts \& Entertainment Law Journal, 2009, p. 375-408.

Keegan $(2020)=$ Rebecca Keegan: A.I. Robot Cast in Lead Role of §70M Sci-Fi Film, The Hollywood Reporter, June 24, 2020 (https://www.hollywoodreporter.com/news/ai-robot-cast-lead-role-70m-sci-fi-film-1300068)

Keh (2019) = Andrew Keh: Gymnastics' Latest Twist? Robot Judges That See Everything, The New York Times, October 10, 2019 (https://www.nytimes.com/2019/10/10/sports/olympics/gymnastics-robot-judges.html)

Kelly (2020) = Éanna Kelly: EU Struggles to Go from Talk to Action on Artificial Intelligence, Science|Business, July 16, 2020 (https://sciencebusiness.net/news/eu-struggles-go-talk-action-artificial-intelligence)

Kessel (2019) = Jonah M. Kessel: Killer Robots Aren't Regulated. Yet, The New York Times, December 13, 2019 (https://www.nytimes.com/2019/12/13/technology/autonomous-weapons-video.html)

Keßler $(2017)=$ Oliver Keßler: Intelligente Roboter - neue Technologien im Einsatz - Voraussetzungen und Rechtsfolgen des Handelns informationstechnischer Systeme, Multimedia und Recht, Issue 9/2017, p. 589-594.

Konar (1999) = Amit Konar: Artificial Intelligence and Soft Computing - Behavioral and Cognitive Modeling of the Human Brain, CRC Press, Boca Raton, 1999

Kop $(2020 a)=$ Mauritz Kop: AI \& Intellectual Property: Towards an Articulated Public Domain, Texas Intellectual Property Law Journal, 2020, p. 1-39. (forthcoming) (https://ssrn.com/abstract=3409715)

Kop $(2020 b)=$ Mauritz Kop: Machine Learning \& EU Data Sharing Practices, TTLF Newsletter on Transatlantic Antitrust and IPR Developments - Stanford-Vienna Transatlantic Technology Law Forum, Issue 1/2020, p. 7-22.

Kur (2020) = Annette Kur: Unité de l'art is Here to Stay - Cofemel and its Consequences, Journal of Intellectual Property Law \& Practice, Issue 4/2020, p. 290-300.

Lambert (2017) = Paul Lambert: Computer-generated Works and Copyright: Selfies, Traps, Robots, AI and Machine Learning, European Intellectual Property Review, Issue 1/2017, p. 12-20.

Lang $(2020)=$ Fabienne Lang: MIT Researchers Turn COVID-19 into a Classical Melody Using AI, Interesting $\begin{array}{llll}\text { Engineering, } & \text { April } & 7, & 2020\end{array}$ (https://interestingengineering.com/mit-researchers-turn-covid-19-into-a-classical-melody-using-ai)

Larsson (2017) Stefan Larsson: Conceptions in the Code - How Metaphors Explain Legal Challenges in Digital Times, Oxford University Press, New York, 2017 
Larsson $(2020)=$ Stefan Larsson: On the Governance of Artificial Intelligence through Ethics Guidelines, Asian Journal of Law and Society, 2020, p. 1-23. (in press)

Larsson / Heintz (2019) = Stefan Larsson / Fredrik Heintz: Transparency in Artificial Intelligence, Internet Policy Review, Issue 2/2019, p. 1-16.

Latournerie (2001) = Anne Latournerie: Petite histoire des batailles du droit d'auteur, Multitudes, 2001/2 n 5, p. 43-46.

Lauber-Rönsberg / Hetmank (2019) = Anne Lauber-Rönsberg / Sven Hetmank: The Concept of Authorship and Inventorship Under Pressure: Does Artificial Intelligence Shift Paradigms?, Journal of Intellectual Property Law \& Practice, Issue 7/2019, p. 570-579.

Leistner (2015) = Matthias Leistner: Copyright at the Interface Between EU Law and National Law: Definition of "Work" and "Right of Communication to the Public", Journal of Intellectual Property Law \& Practice, Issue 8/2015, p. 626-637.

Lemley / Casey (2020) = Mark A. Lemley / Bryan Casey: Fair Learning, 2020, p. 1-64. (https://ssrn.com/abstract=3528447)

Leonard (2013) = Michael Leonard: Meet Compressorhead - The World's Most Metal Band, Gibson.com, April 9, 2013

(http://www2.gibson.com/News-Lifestyle/Features/en-us/Meet-Compressorhead-The-Worlds-Most-Metal-Band.a $\underline{\mathrm{spx}})$

Lim (2018) $=$ Milton Lim: History of AI Winters, Actuaries Digital, September 5, 2018 (https://www.actuaries.digital/2018/09/05/history-of-ai-winters/)

Linke / Petrlík (2020) = David Linke / David Petrlík: "Copyright Work and Its Definition With Regard to Originality and AI" - Conference Report on the 4th Binational Seminar of the TU Dresden and the Charles University in Prague, June 27, 2019, Gewerblicher Rechtsschutz und Urheberrecht Internationaler Teil, Issue 1/2020, p. 39-45.

Litman (2006) = Jessica Litman: Digital Copyright, Prometheus Books, Amherst, 2006

Liu (2018) = Deming Liu: Forget the Monkey Copyright Nonsense for Goodness Sake, Dude!, European Intellectual Property Review, Issue 1/2018, p. 61-65.

Lohsse / Schulze / Staudenmayer (2019) = Sebastian Lohsse / Reiner Schulze / Dirk Staudenmayer (Eds.): Liability for Artificial Intelligence and the Internet of Things, Nomos-Hart, Baden-Baden, 2019

Maggiore (2018) = Massimo Maggiore: Artificial Intelligence, Computer Generated Works and Copyright. In: Enrico Bonadio / Nicola Lucchi: Non-Conventional Copyright - Do New and Atypical Works Deserve Protection?, Edward Elgar, Cheltenham, 2018, p. 382-399.

Magrani (2019) = Eduardo Magrani: New Perspectives on Ethics and the Laws of Artificial Intelligence, Internet Policy Review, Issue 3/2019, p. 1-19.

Margoni (2018) = Thomas Margoni: Artificial Intelligence, Machine Learning and EU Copyright Law: Who Owns AI?, CREATe Working Paper 2018/12, December 2018, p. 1-21.

Matthews (1890) = Brander Matthews: The Evolution of Copyright, Political Science Quarterly, 1890, p. 583-602.

McCutcheon (2013a) = Jani McCutcheon: The Vanishing Author in Computer-Generated Works: A Critical Analysis of Recent Australian Case Law, Melbourne University Law Review, Vol. 36, 2013, p. 915-969.

McCutcheon $(2013 b)=$ Jani McCutcheon: Curing the Authorless Void: Protecting Computer-Generated Works Following ICETV and Phone Directories, Melbourne University Law Review, Vol. 37, 2013, p. 46-102.

McLeod Blythe (2020) = Stephen McLeod Blythe: Copyright Filters and AI Fails: Lessons from Banning Porn, European Intellectual Property Review, Issue 2/2020, p. 119-125.

Metz (2019) = Cade Metz: Google Claims a Quantum Breakthrough That Could Change Computing, The New York Times, October 23, 2019 (https://www.nytimes.com/2019/10/23/technology/quantum-computing-google.html)

Meys (2020) = Romain Meys: Data Mining Under the Directive on Copyright and Related Rights in the Digital Single Market: Are European Database Protection Rules Still Threatening the Development of Artificial Intelligence?, GRUR International, Issue 5/2020, p. 457-473.

Mezei (2014) = Péter Mezei: The Role of Technology and Consumers' Needs in the Evolution of Copyright Law - From Gutenberg to the Filesharers. In: Éva Jakab (Hrsg.): Geistiges Eigentum und Urheberrecht aus der historischen Perspektive, Lectiones Iuridicae 10, Pólay Elemér Alapítvány, Szeged, 2014, p. 71-79.

Mezei (2020) = Péter Mezei: Intervention to WIPO's AI and IP Conversation, Copy21 Blog, June 23, 2020 (http://copy21.com/2020/06/intervention-to-wipos-ai-and-ip-conversation/)

Munro $(2016)$ = Cait Munro: Meet Berenson, the Robot Art Critic, Artnet News, February 29, 2016 (https://news.artnet.com/art-world/robot-art-critic-berenson-436739)

Nägele / Apel (2020) = Thomas Nägele / Simon Apel: KI und Urheberrecht. In: Markus Kaulartz / Tom Braegelmann: Rechtshandbuch Artificial Intelligence und Machine Learning, C.H. Beck-Wahlen, 2020, p. 289-309. 
Nahmias / Perel (2020) = Yifat Nahmias / Maayan Perel: The Oversight of Content Moderation by AI: Impact Assessments and Their Limitations, Harvard Journal of Legislation, 2020, p. 1-54. (forthcoming) (https://ssrn.com/abstract=3565025)

Naudé (2019) = Wim Naudé: AI's Current Hype and Hysteria Could Set the Technology Back by Decades, The Conversation, July 24, 2019 (http://theconversation.com/ais-current-hype-and-hysteria-could-set-the-technology-back-by-decades-120514)

Netanel (1996) $=$ Neil Weinstock Netanel: Copyright and a Democratic Civil Society, Yale Law Journal, 1996, p. 283-387.

Nevejans $(2016)=$ Nathalie Nevejans: European Civil Law Rules in Robotics, European Union, 2016 (https://www.europarl.europa.eu/RegData/etudes/STUD/2016/571379/IPOL_STU(2016)571379_EN.pdf)

$\mathrm{Ng}$ Boyte (2014) = Alina Ng Boyte: The Conceits of our Legal Imagination: Legal Fiction and the Concept of Deemed Authorship, Legislation and Public Policy, 2014, p. 707-762.

Nilsson (2010) = Nils J. Nilsson: The Quest for Artificial Intelligence: A History of Ideas and Achievements, Cambridge University Press, Cambridge, 2010

Nordemann / Vinck / Hertin / Meyer (1990) = Wilhelm Nordemann / Kai Vinck / Paul W. Hertin / Gerald Meyer: International Copyright and Neighboring Rights Law: Commentary with Special Emphasis on the European Community, Wiley-VCH, Weinheim, 1990

Noto La Diega (2018) = Guido Noto La Diega: Artificial Intelligence and Databases in the Age of Big Machine, AIDA, 2018, p. 93-149.

O'Neill (2020) = Rory O'Neill: AI-written articles are copyright-protected, rules Chinese court, World IP Review, January 10 , 2020 (https://www.worldipreview.com/news/ai-written-articles-are-copyright-protected-rules-chinese-court-19102)

Opitz (2020) = Paul Opitz: European Commission Working on Ethical Standards for Artificial Intelligence (AI), TTLF Newsletter on Transatlantic Antitrust and IPR Developments - Stanford-Vienna Transatlantic Technology Law Forum, Issue 2/2018, p. 28-30.

Oremus (2014) $=$ Will Oremus: The First News Report on the L.A. Earthquake Was Written by a Robot, Slate, March 17 , 2014 (https://slate.com/technology/2014/03/quakebot-los-angeles-times-robot-journalist-writes-article-on-la-earthquak e.html)

Osha (2019) = Jonathan P. Osha: Summary Report - Copyright in artificially generated works, AIPPI, July 1, 2019 (https://aippi.org/wp-content/uploads/2019/08/SummaryReport_COPYRIGHT-DATA_London2019 final_16071 9.pdf)

Oster (2018) = Jan Oster: Haftung für Persönlichkeitsrechtsverletzungen durch Künstliche Intelligenz, UFITA - Archiv für Medienrecht und Medienwissenschaft, Heft 1/2018, p. 14-52.

Pagallo / Corrales / Fenwick / Forgó (2018) = Ugo Pagallo / Marcelo Corrales / Mark Fenwick / Nikolaus Forgó: The Rise of Robotics \& AI: Technological Advances \& Normative Dilemmas. In: Corrales/Fenwick/Forgó (2018) 1-13.

Palace (2019) = Victor M. Palace: What if Artificial Intelligence Wrote This? Artificial Intelligence and Copyright Law, Florida Law Review, 2019, p. 217-242.

Palazzetti (2020) = Laura Palazzetti: Artificial Intelligence and the Challenges of the Fashion Industries, Ius in itinere, June 25 ,

2020 (https://www.iusinitinere.it/artificial-intelligence-and-the-challenges-of-the-fashion-industries-29023)

Patterson / Birch / Joyce (2009) = L. Ray Patterson / Stanley F. Birch / Craig Joyce: A Unified Theory of Copyright Chapter 2: The Copyright Clause and Copyright History, Houston Law Review, 2009, p. 244-256.

Pila / Torremans (2016) = Justine Pila / Paul L. C. Torremans: European Intellectual Property Law, Oxford University Press, New York, 2016

Price / Pollack (1992) $=$ Monroe Price / Malla Pollack: The Author in Copyright: Notes for the Literary Critic, Cardozo Arts and Entertainment Law Journal, 1992, p. 703-720.

Prosser (2020) Marc Prosser: How AI Helped Predict the Coronavirus Outbreak Before It Happened, SingularityHub, February $\quad$ 5, 2020 (https://singularityhub.com/2020/02/05/how-ai-helped-predict-the-coronavirus-outbreak-before-it-happened/)

Rahmatian (2019) = Andreas Rahmatian: Originality in UK Copyright Law: The Old "Skill and Labour" Doctrine Under Pressure, IIC - International Review of Intellectual Property and Competition Law, Issue 8/2019, p. 4-34.

Ralston (2005) = William T. Ralston: Copyright in Computer-Composed Music: HAL meets Handel, Journal of the Copyright Society U.S.A., 2005, p. 281-307.

Ramalho (2017) = Ana Ramalho: Will Robots Rule the (Artistic) World?: A Proposed Model for the Legal Status of Creations by Artificial Intelligence Systems, Journal of Internet Law, Issue 1/2017, p. 1 and 12-25. 
Rensselaer Polytechnic Institute (1998) = Rensselaer Polytechnic Institute: A Silicon Hemingway - Artificial Author

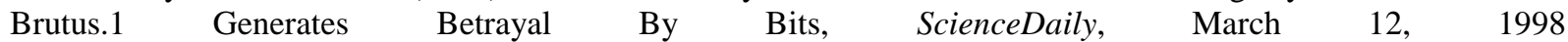
(www.sciencedaily.com/releases/1998/03/980312075430.htm)

Revolidis / Dahi (2018) = Ioannis Revolidis / Alan Dahi: The Peculiar Case of the Mushroom Picking Robot: Extra-contractual Liability in Robotics. In: Corrales/Fenwick/Forgó (2018) 57-79.

Ricketson - Ginsburg (2005) = Sam Ricketson - Jane C. Ginsburg: International Copyright and Neighbouring Rights: The Berne Convention and Beyond - Volume One, Second Edition, Oxford University Press, 2005

Ricketson $(1991)=$ Sam Ricketson: The 1992 Horace S. Manges Lecture - People or Machines: The Berne Convention and the Changing Concept of Authorship, Columbia-VLA Journal of Law \& the Arts, Issue 1/1991, p. 1-37.

Rideau (2016) = Frédéric Rideau: Aspects of French Literary Property Developments in the Eighteenth (and Nineteenth) Centuries. In: Alexander / Gómez-Arestegui (2016) 391-422.

Rohner (2019) $=$ Tim Rohner: Der Schutz von KI-Schöpfungen im schweizerischen Urheberrecht, Zeitschrift für geistiges Eigentum / Intellectual Property Journal, Issue 1/2019, p. 33-85.

Rosati (2013) = Eleonora Rosati: Originality in EU Copyright - Full Harmonization through Case Law, Edward Elgar, Cheltenham, 2013

Rosati (2019) = Eleonora Rosati: Copyright as an Obstacle or an Enabler? A European Perspective on Text and Data Mining and its Role in the Development of AI Creativity, Asia Pacific Law Review, Issue 2/2019, p. 198-217.

Rose (2010) = Mark Rose: The Public Sphere and the Emergence of Copyright: Areopagitica, the Stationers Company, and the Statute of Anne. In: Ronan Deazley / Martin Kretschmer / Lionel Bently: Privilege and Property - Essays on the History of Copyright, Open Book Publishers, Cambridge, 2010, p. 67-88.

Samuelson (1986) = Pamela Samuelson: Allocating Ownership Rights in Computer-Generated Works, University of Pittsburgh Law Review, 1985-1986, p. 1185-1228.

Schiller (2016) = Ben Schiller: This Japanese Novel Authored By A Computer Is Scarily Well-Written, Fast Company, March 28, 2016 (https://www.fastcompany.com/3058300/this-japanese-novel-authored-by-a-computer-is-scarily-well-written)

Schönberger (2018) = Daniel Schönberger: Deep Copyright: Up- and Downstream Questions Related to Artificial Intelligence (AI) and Machine Learning (ML). In: Jacques De Werra (Ed.): Droit d'auteur 4.0 / Copyright 4.0, Schultess Editions Romandes, Geneva / Zurich, 2018, p. 145-173.

Schricker (1995) = Gerhard Schricker: Farewell to the "Level of Creativity" (Schöpfungshöhe) in German Copyright Law?, IIC - International Review of Intellectual Property and Competition Law, Issue 1/1995, p. 41-48.

Segawa (2016) = Natsuko Segawa: Japan eyes rights protection for AI artwork, Nikkei Asian Review, April 15, 2016 (https://asia.nikkei.com/Politics-Economy/Economy/Japan-eyes-rights-protection-for-AI-artwork)

Séjourné $(2020)=$ Draft Report on intellectual property rights for the development of artificial intelligence technologies (2020/2015(INI)), Committee on Legal Affairs, Rapporteur: Stéphane Séjourné, April 24, 2020 (https://www.europarl.europa.eu/doceo/document/JURI-PR-650527_EN.html?redirectI)

Selvadurai / Matulionyte (2020) = Niloufer Selvadurai / Rita Matulionyte: Reconsidering Creativity: Copyright Protection for Works Generated Using Artificial Intelligence, Journal of Intellectual Property Law \& Practice, Issue 7/2020, p. 536-543.

Senftleben $(2020)=$ Martin Senftleben: The Original Sin - Content 'Moderation' (Censorship) in the EU, GRUR International, Issue 4/2020, p. 339-340.

Siegel $(2020)=$ Tatiana Siegel: Warner Bros. Signs Deal for AI-Driven Film Management System (Exclusive), The Hollywood Reporter, $\quad$ January 2020 (https://www.hollywoodreporter.com/news/warner-bros-signs-deal-ai-driven-film-management-system-1268036)

Sobel (2017) = Benjamin L. W. Sobel: Artificial Intelligence's Fair Use Crisis, Columbia-VLA Journal of Law \& the Arts, Issue 1/2017, p. 45-97.

Spindler $(2019)=$ Gerald Spindler: Copyright Law and Artificial Intelligence, IIC - International Review of Intellectual Property and Competition Law, Issue 9/2019, p. 1049-1051.

Starr $(2013)=$ Michelle Starr: Meet e-David, the robot that paints, CNET, July 12, 2013 (https://www.cnet.com/news/meet-e-david-the-robot-that-paints/)

Sundara Rajan (2011) = Mira T. Sundara Rajan: Moral Rights - Principles, Practice and New Technology, Oxford University Press, New York, 2011

Suthersanen / Mimler (2020) = Uma Suthersanen / Marc D. Mimler: An Autonomous EU Functionality Doctrine for Shape Exclusions, GRUR International, Issue 6/2020, p. 567-577.

Synodinou (2012) = Tatiana-Eleni Synodinou: The Foundations of the Concept of Work in European Copyright Law. In: Tatiana-Eleni Synodinou (Ed.): Codification of European Copyright, Challenges and Perspectives, Kluwer Law International, Alphen aan den Rijn, 2012, p. 93-113. 
Tamura (2009) = Yoshiyuki Tamura: Rethinking Copyright Institution for the Digital Age, WIPO Journal, Issue 2009/1, p. 63-74.

Tencent Dreamwriter (2020) = Tencent Dreamwriter, Decision of the People's Court of Nanshan (District of Shenzen), 24 December 2019 - Case No. (2019) Yue 0305 Min Chu No. 14010, IIC - International Review of Intellectual Property and Competition Law, Issue 5/2020, p. 652-659.

Thampapillai (2019) = Dilan Thampapillai: If Value Then Right: Copyright and Artificial Intelligence, Australian Intellectual Property Journal, Issue 2/2019, p. 96-113.

The Economist $(2020)=$ For AI, data are harder to come by than you think, The Economist, June 11, 2020 (https://www.economist.com/technology-quarterly/2020/06/11/for-ai-data-are-harder-to-come-by-than-you-think)

Truong (2020) = Kevin Truong: The Record Industry Is Going After Parody Songs Written by an Algorithm, Vice, July 22 ,

(https://www.vice.com/en_ca/article/m7jpp3/the-record-industry-is-going-after-parody-songs-written-by-an-algor ithm)

Turner (2018) = Jacob Turner: Robot Rules - Regulating Artificial Intelligence, Palgrave Macmillan, Cham, 2018

U.S. Copyright Office (2017) $=$ U.S. Copyright Office: Compendium of U.S. Copyright Office Practices, $3^{\text {rd }}$ Edition, 2017

van den Hoven van Genderen (2018) = Robert van den Hoven van Genderen: Do We Need New Legal Personhood in the Age of Robots and AI?. In: Corrales/Fenwick/Forgó (2018) 15-56.

Vanherpe (2020) = Josefien Vanherpe: AI and IP - a Tale of Two Acronyms. In: Jan De Bruyne - Cedric Vanleenhove (Eds.): Robots, AI and the Law in Belgium, Intersentia, Antwerp/Cambridge, 2020 (forthcoming)

Wakefield (2020) = Jane Wakefield: Artificial intelligence-created medicine to be used on humans for first time, $B B C$, January 30, 2020 (https://www.bbc.com/news/technology-51315462)

Walter $(2020)=$ Michel Walter: Der unionsrechtliche Werkbegriff und die Werke der angewandten Kunst- Zugleich Anmerkung zu EuGH „Cofemel” C-683/16, Medien und Recht International, Issue 1/2020, p. 3-8.

Walz (2017) = Axel Walz: A Holistic Approach to Developing an Innovation-Friendly and Human-Centric AI Society, International Review of Intellectual Property and Competition Law, Issue 2/2017, p. 757-759.

White Paper on Artificial Intelligence, $\operatorname{COM}(2020) 65$ final (2020) = White Paper on Artificial Intelligence - A European Approach to Excellence and Trust, $\operatorname{COM}(2020) 65$ final, Brussels, 19.2.2020 (https://ec.europa.eu/info/publications/white-paper-artificial-intelligence-european-approach-excellence-and-trust en)

Wolff (2019) = Lutz-Christian Wolff: Artificial Intelligence ante portas: The End of Comparative Law?, The Chinese Journal of Comparative Law, Issue 3/2019, p. 484-504.

Yamamoto (2018) = Takashi Yamamoto: AI Created Works and Copyright, Patents \& Licensing, Issue 1/2018, p. 1-16.

Yan (2020) = Li Yan: Court rules AI-written article has copyright, ECNS.cn, January 9, 2020 (http://www.ecns.cn/news/2020-01-09/detail-ifzsqcrm6562963.shtml)

Yanisky-Ravid (2017) = Shlomit Yanisky-Ravid: Generating Rembrandt: Artificial Intelligence, Copyright, and Accountability in the 3A Era - The Human-Like Authors Are Already Here - A New Model, Michigan State Law Review, 2017, p. 659-726.

Yanisky-Ravid / Velez-Hernandez (2018) = Shlomit Yanisky-Ravid / Luis Antonio Velez-Hernandez: Copyrightability of Artworks Produced by Creative Robots and Originality: The Formality-Objective Model, Minnesota Journal of Law, Science \& Technology, Issue 1/2018, p. 1-53.

Zech $(2019)=$ Herbert Zech: Künstliche Intelligenz und Haftungsfragen, Zeitschrift für die gesamte Privatrechtswissenschaft, Heft 2/2019, p. 198-219.

Zech (2020) = Herbert Zech: Artificial Intelligence: Impact of Current Developments in IT on Intellectual Property, Gewerblicher Rechtsschutz und Urheberrecht Internationaler Teil, Issue 12/2019, p. 1145-1147.

Zibner (2019) = Jan Zibner: Artificial Intelligence: A Creative Player in the Game of Copyright, European Journal of Law and Technology, Issue 1/2019, p. 1-20. (http://www.ejlt.org/index.php/ejlt/article/view/662/885) 